\title{
Ethnopharmacological review of medicinal plants used to manage diabetes in Morocco
}

\author{
Elhassan Idm'hand*, Fouad Msanda and Khalil Cherifi
}

\begin{abstract}
Diabetes is a chronic metabolic disorder which affects millions of people every year. If diabetes is not controlled, it can cause serious damage and a number of health complications. The aim of this paper was to review published ethnobotanical and ethnopharmacological evidences of Moroccan plants with antidiabetic potentials. Publications describing the medicinal plants used for the treatment of diabetes in Morocco were searched from the databases, including Google Scholar, Elsevier, Medline, Web of Science, SCOPUS and Pubmed. Other literature source was also used including books and theses available in library. About 750 literature references were studied, and only 240 research publications based on data from different Moroccan provinces published until June 2019 were included in this review. In total, 255 plants species belonging to 70 families were reported. Compositae and Lamiaceae were mentioned as the most represented families. The frequently used plant species in the dwellers of most regions of Morocco are Trigonella foenum-graecum, Artemesia herba-alba, Nigella sativa, Olea europaea, Allium cepa and Marrubium vulgare. This review provides useful information and current scientific knowledge on the medicinal plants used to manage diabetes in Morocco. Medicinal plants reported should be submitted to chemical, pharmacological and clinical studies to identify pharmacologically active metabolites and to confirm their antidiabetic activity.
\end{abstract}

Keywords: Medicinal plants, Diabetes, Ethnobotany, Pharmacology, Toxicology, Morocco

\section{Introduction}

Type 2 diabetes mellitus (T2DM), generally termed as diabetes, is one of the major endocrine diseases which affects millions of people in the industrial and developing countries $[1,2]$. It is projected that the total number of people with diabetes worldwide is expected to increase to 592 million by 2035 [3]. Diabetes is a metabolic disease characterized by insufficient insulin secretion, impaired cellular action of the insulin or both $[2,4]$. The characteristic symptoms of diabetes are pruritus, polydipsia, weight loss, polyphagia, wasting, blurred vision, polyuria, tachycardia and hypotension [5, 6]. Dietary and lifestyle factors (Obesity, weight gain, physical inactivity and low fiber diet with a high glycemic index) play a

\footnotetext{
* Correspondence: idmhand-h@hotmail.com

Laboratoire de Biotechnologies et Valorisation des Ressources Naturelles, Faculté des Sciences, B.P. 8106, Cité Dakhla, Agadir, Morocco
}

significant role in the development of diabetes [7]. Prolonged uncontrolled hyperglycemic level causes an increase in oxidative stress activation of the polyol pathway, coronary artery disease, peripheral arterial disease, stroke, diabetic nephropathy, neuropathy, peripheral neuropathy, retinopathy, retinopathy leading to vision loss, chronic kidney disease, urinary problems, sexual dysfunction, and skin infections $[3,8,9]$. The treatment of diabetes mellitus is based on insulin, diet modification and oral hypoglycemic agents. Herbal medicine has developed as an alternative for the treatment of diabetes because oral hypoglycemic agents are expensive and tagged with several side effects (nausea, skin reactions, liver disease, heart failure diarrhea, etc.) $[10,11]$. In Morocco, there are numerous medicinal plants described for treatment of diabetes [2, 12-23].

\section{Springer Open}

(๑) The Author(s). 2020 Open Access This article is licensed under a Creative Commons Attribution 4.0 International License, which permits use, sharing, adaptation, distribution and reproduction in any medium or format, as long as you give appropriate credit to the original author(s) and the source, provide a link to the Creative Commons licence, and indicate if changes were made. The images or other third party material in this article are included in the article's Creative Commons licence, unless indicated otherwise in a credit line to the material. If material is not included in the article's Creative Commons licence and your intended use is not permitted by statutory regulation or exceeds the permitted use, you will need to obtain permission directly from the copyright holder. To view a copy of this licence, visit http://creativecommons.org/licenses/by/4.0/. 
The aim of this review article was to collect data for species wellknown for their antidiabetic effect in Morocco.

\section{Method}

Three researchers searched Google Scholar, Elsevier, Medline, Web of Science, SCOPUS and Pubmed bibliographic databases from January 2019 to July 2019 to extract all data about the use of plants in folklore medicine for treatment and management of diabetes in Morocco published in the period from January 1980 to June 2019, using English, French and Arabic keywords. The search terms used were "Ethnobotanical survey", "Moroccan medicinal plants", "anti-diabetic medicinal plants in Morocco", "hypoglycemic plants in Morocco", "diabetes in Morocco". We reviewed the literature and collected data on the explored regions of Morocco (Beni Mellal region, Rabat, Western Anti-Atlas, Izarene forest, Oriental Morocco, Northwestern Morocco, Sefrou region, Central Middle Atlas, Tizi n' Test Region, Al HaouzRhamna, Tan-Tan, Meknes-Tafilalet and Fez-Boulemane). About 750 literature references were studied, and only 240 ethnobotanical articles and pharmacology papers were included in this review. We did not included articles related to taxonomy, morphological characters, pharmacology, toxicity, ethnobotany, phytochemistry, clinical studies, cultivation, physiological, and anatomical aspects of all the medicinal plants mentioned. We studied in detail only the six plants most used for the treatment of diabetes in Morocco. We also excluded the articles without accessible full text and duplicate articles. Plant taxonomy is confirmed through data available on site (www.theplantlist.org).

\section{Results}

\section{Ethnobotanical studies}

A total of 255 plant species belonging to 70 families were reported as being used in the treatment and management of diabetes in Morocco (Table 1). Among plant families, Compositae had the highest number of species followed by Lamiaceae, Leguminosae, Apiaceae, Poaceae and Brassicaceae. Compositae was the most frequently cited plant family, which is consistent with the predominance of this plant family in the results of various studies conducted in other countries $[3,27,28]$. Compositae has been designated as the largest plant family of flowering plants worldwide, comprising 23,000 species and 1535 genera, including many with considerable medicinal importance $[29,30]$. The traditional medicinal applications of several Compositae species have been recorded in the literature. Several bioactive compounds have been evaluated for their biological activities [31]. A wide use of Compositae family plants in Morocco could be due to the large number of plant species belonging to this family. Further, plants belonging to the Compositae family contain a group of active phytochemical constituents and some bitter-tasting secondary metabolites such as sesquiterpene lactones $[8,30]$.

Our evaluation of literature showed that indigenous people used 19 plant parts (leaf, aerial part, fruit, leafy stem, seed, root, bark, calyce, flower, stem, clove, gum, inflorescence, bark, pericarp, rhizome, stigma, tuber and young sprout) as herbal therapies for curing diabetes, but with, however, some preference for the leaves. Several procedures modes are used by the population to create medicinal formulations (decoction, cooked, infusion, powder, maceration, juice, raw and cataplasm). However, extractions by decoction, powder or infusion remain the most common processes. Most medicinal formulations were used internally via oral route. The dose used varied considerably according to the patients questioned. The patients did not respect the precision of doses (some diabetics use specific doses, and others use non-specific doses). Often, people use a mixture of plants to treat diabetes. The duration of the use of plants was badly defined ranging from a few days to several years. The majority of people with diabetes have recourse in medicinal plants to treat diabetes. The percentage of use of phytotherapy varies between $51 \%$ and $90 \%$, depending on the regions. The use of herbal medicine among certain diabetics was done in combination with their conventional treatment. Women frequently used more medicinal plants than men. Diabetics have discovered the disease by suggestive symptoms or by a screening test.

An ethnobotanical study was conducted out among 400 herbalists from the Beni Mellal region in order to identify the medicinal plants used for the traditional treatment by the diabetic patients. The results identified 45 species belonging to 25 botanical families. The most used species are: Olea europaea, Salvia officinalis, Allium sativum and Trigonella foenum-graecum. Leaves and roots are the most used parts [24].

To collect some information about antidiabetic plants used in Rabat (capital city of Morocco), a survey was undertaken from March 1st to April 30th 2018. The investigations revealed 30 species of plants belonging to 18 families. Lamiaceae and Leguminosae were the most commonly reported plant families. Interview results showed that the most frequently used plants were Trigonella foenumgraecum, Salvia officinalis and Olea europaea [25].

A survey was conducted by Barkaoui et al. [2], in Tiznit (Western Anti-Atlas), in central Morocco. This study showed the importance of the use of medicinal plants by local population in the treatment of diabetes. Results have identified 48 medicinal plant species, belonging to 25 families and 44 genera, used for treating diabetes in the region. Plants growing in wild are most commonly 


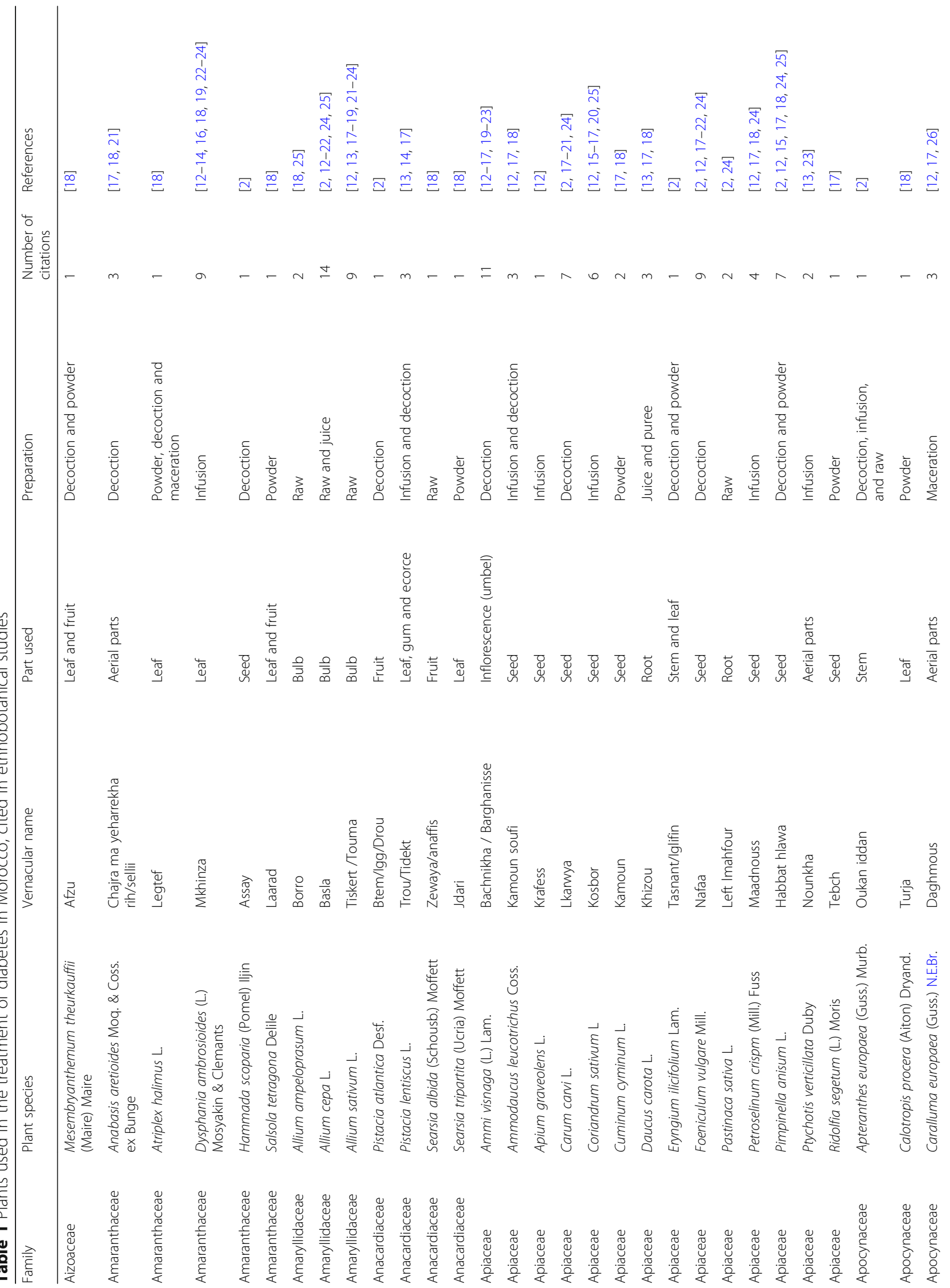




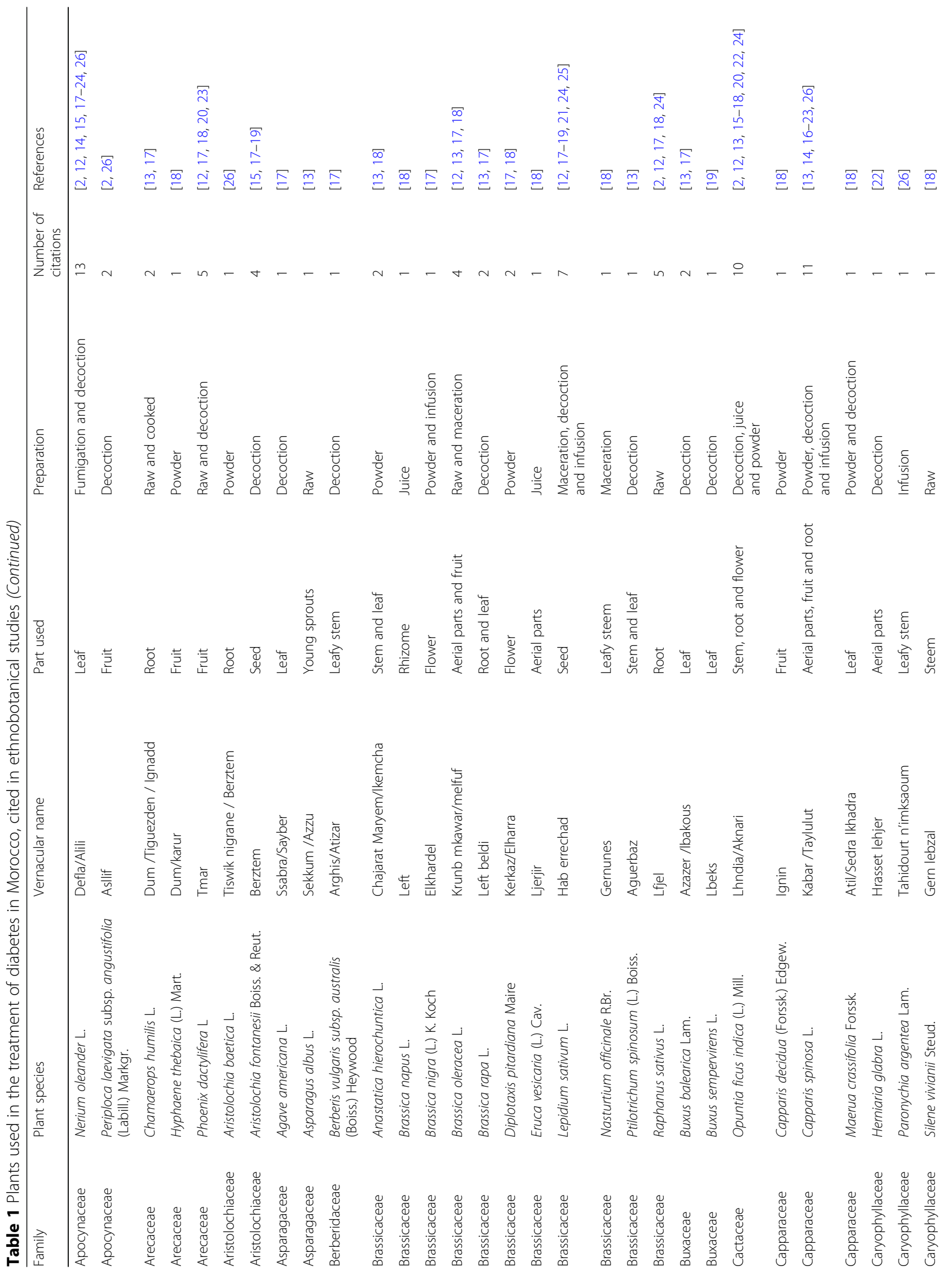




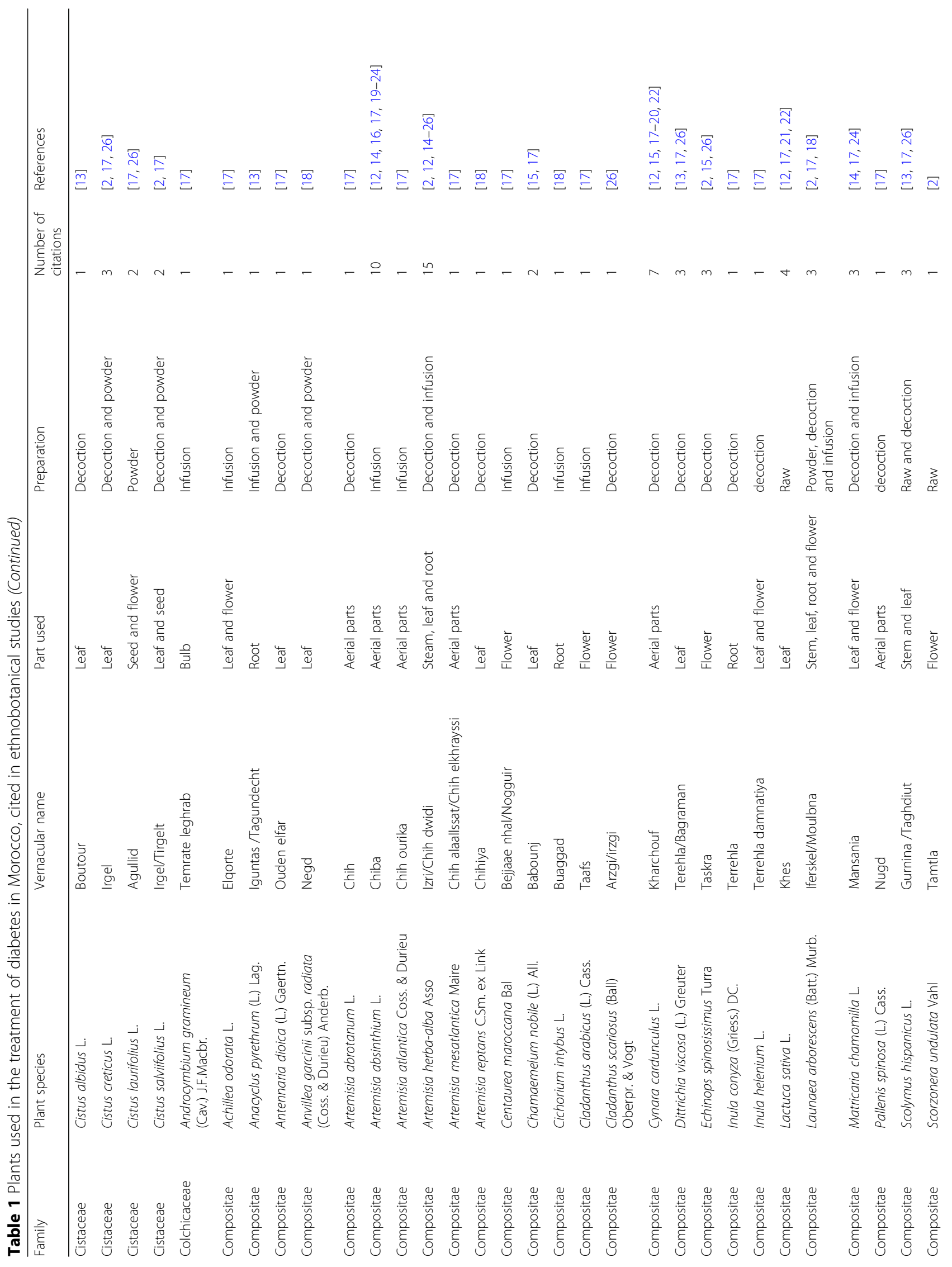




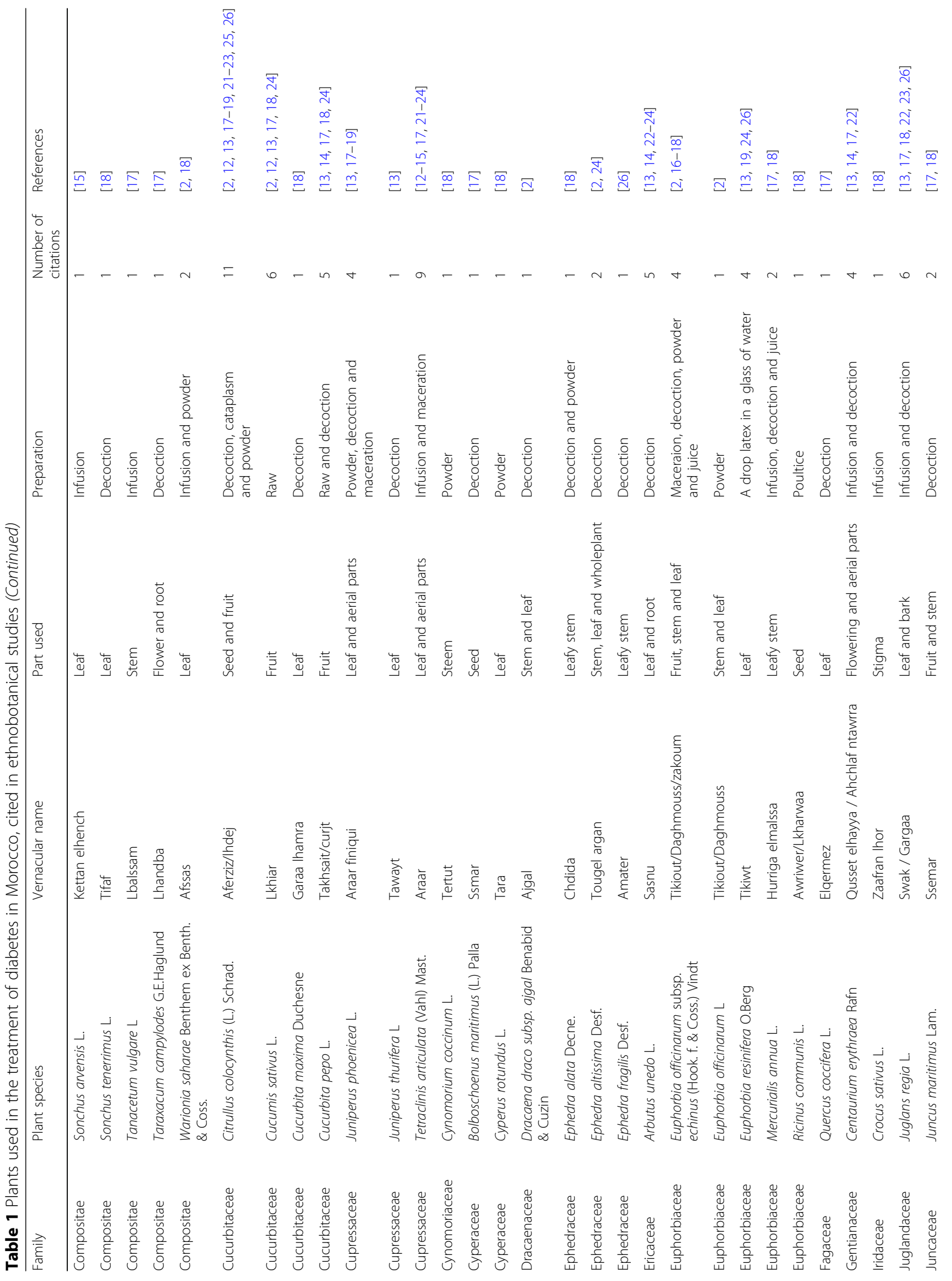




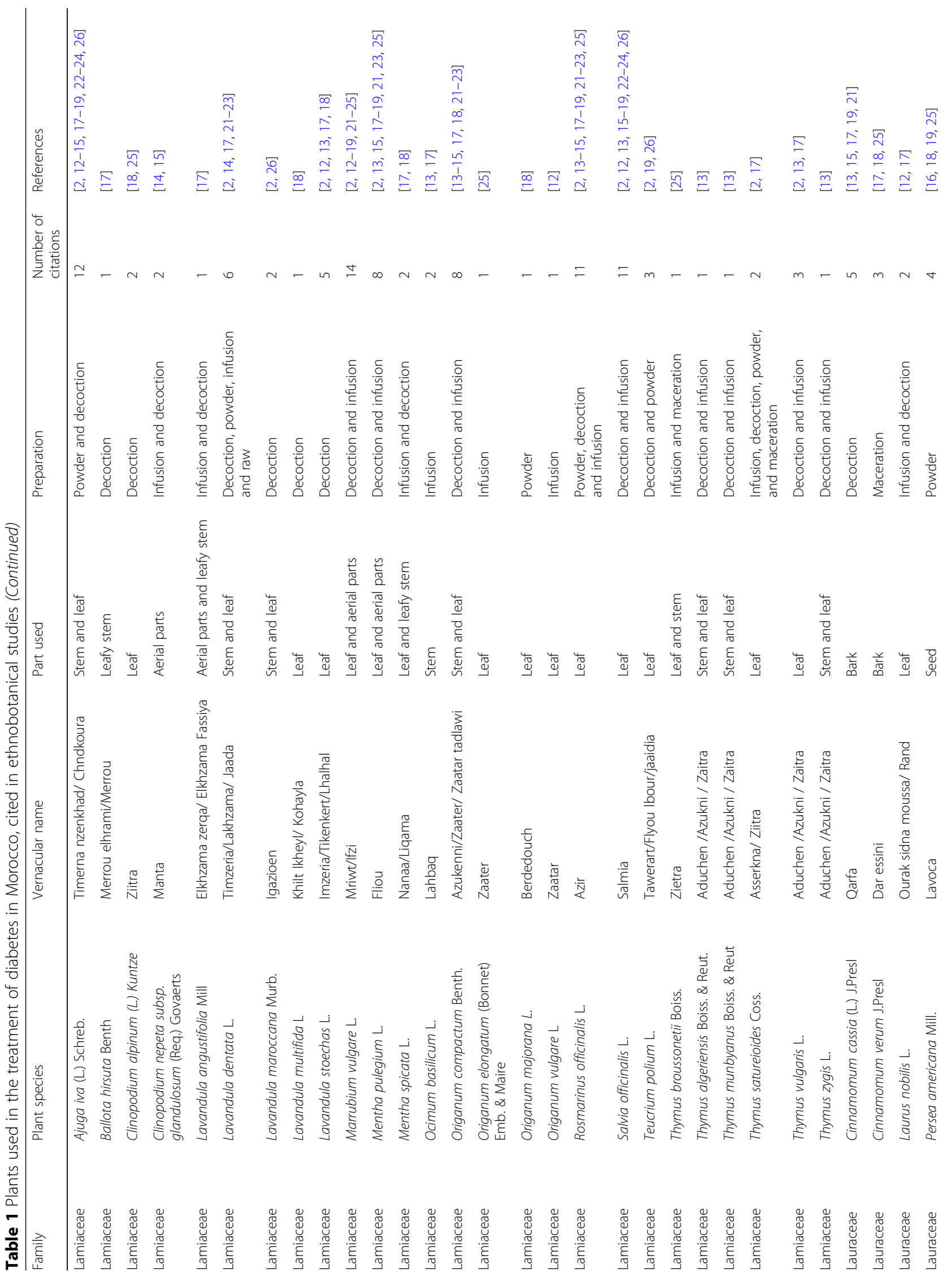




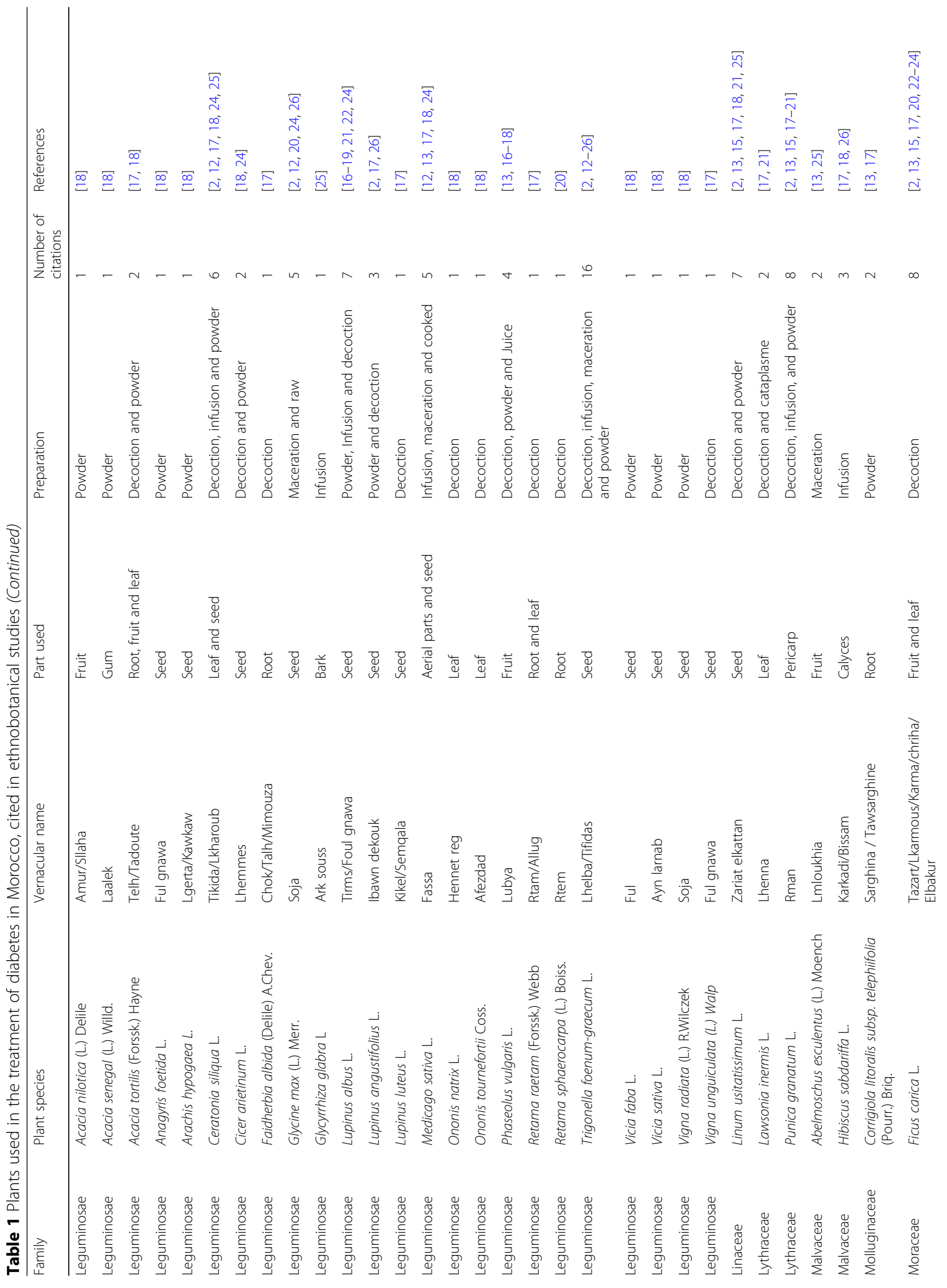




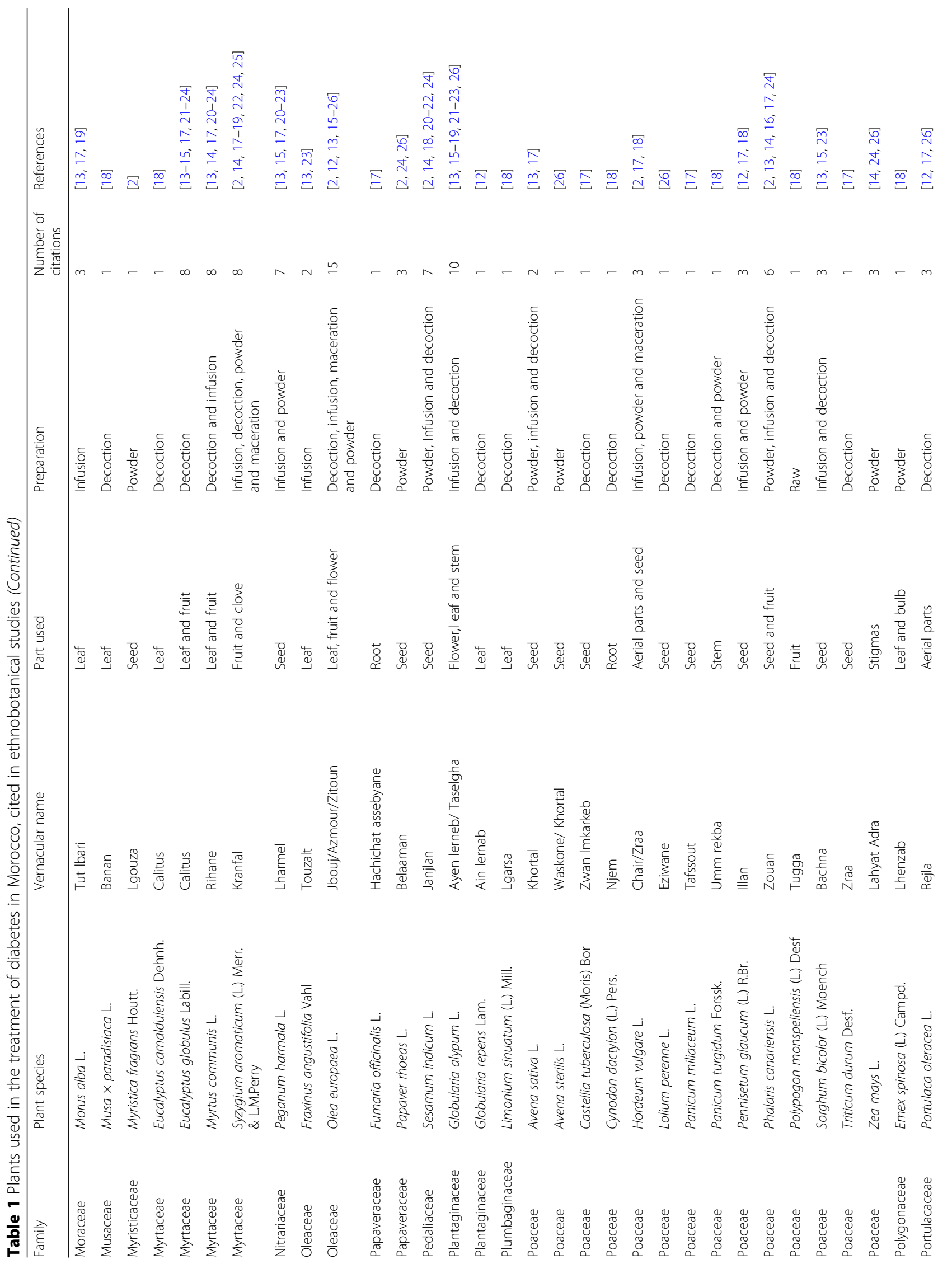




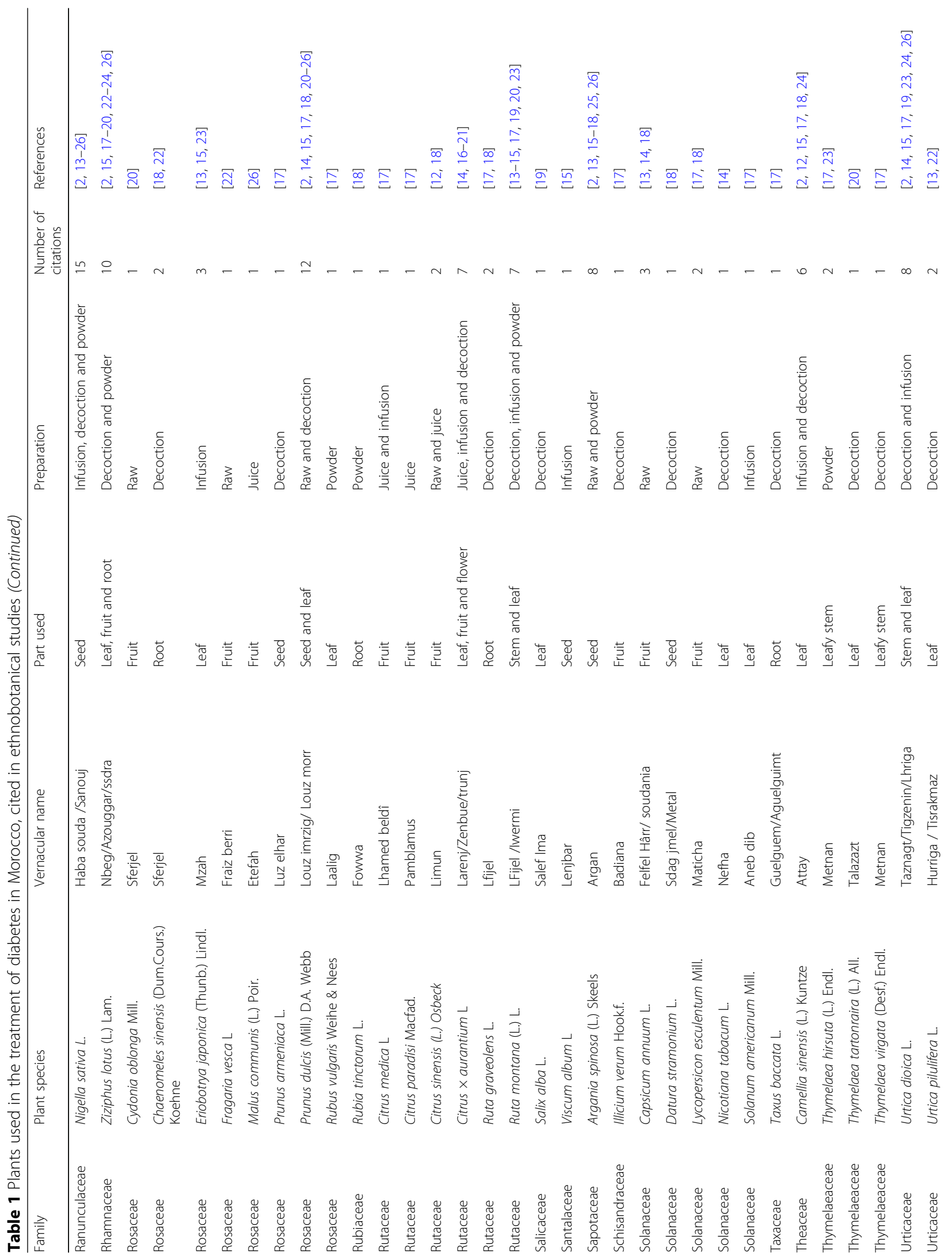




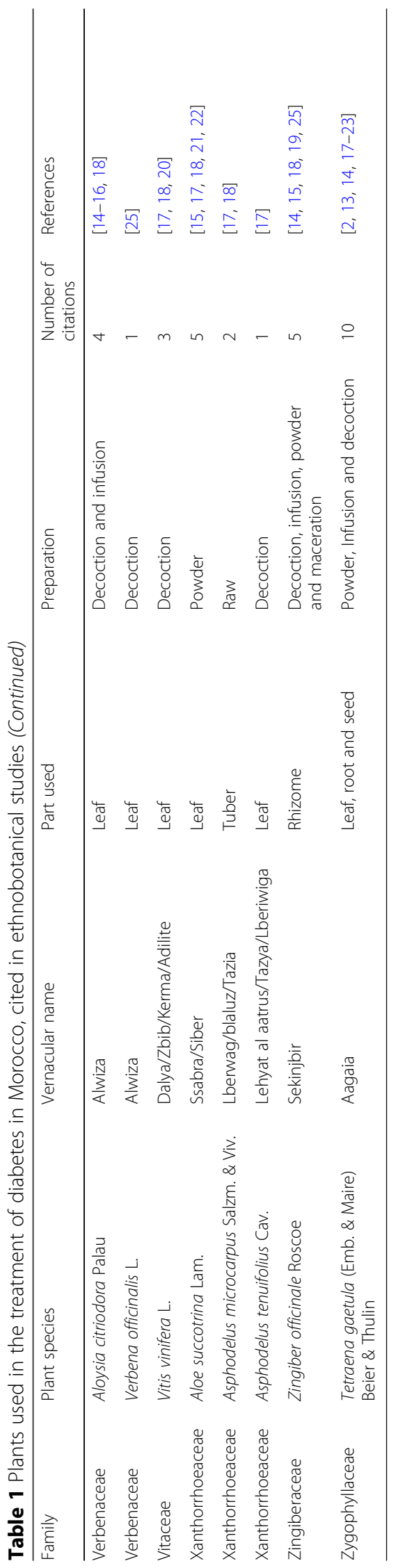


used for medicinal purposes in the study area (32 plant species). According to the authors, Allium sativum L., Salvia officinalis L., Marrubium vulgare L. and Lavandula dentata $\mathrm{L}$ were the most frequently used plants to treat diabetes. Six plants were reported for the first time as hypoglycemic plants: Dracaena draco subsp. ajgal, Euphorbia officinarum subsp. officinarum, Eryngium ilicifolium Lam., Pastinaca sativa L., Scorzonera undulata, Ephedra altissima Desf.

In Izarene forest (Northern Morocco), a survey was undertaken in order to inventory the main medicinal plants used in folk medicine to treat diabetes and arterial hypertension. The results obtained allowed an inventory of 40 medicinal plant species used against diabetes. The most cited plants for the treatment of diabetes were: Trigonella foenum-graecum, Artemisia herba-alba, Ammi visnaga, Centaurium erythreae, Myrtus communis, Globularia alypum, Nigella sativa, Tetraena gaetula, Olea europaea, Rosmarinus officinalis, Marrubium vulgare, Allium cepa, Ajuga iva, Salvia officinalis, Artemesia absinthium, Prunus dulcis, Capsicum annuum, Origanum compactum, Nerium oleander, and Urtica dioica [14].

An ethnobotanical survey by Ziyyat et al. [23] in different areas of Oriental Morocco reported that 34 plant species were used for the treatment of diabetes, of which the most used were Trigonella foenum-graecum, Globularia alypum, Artemisia herba-alba, Citrullus colocynthis and Tetraclinis articulata. Also a study was carried out in Oriental Morocco with 279 diabetic patients at the Department of Endocrinology and Metabolism of Mohammed VI Uneversity Hospitalin Oujda. The results showed that the local population uses medicinal plants for the treatment of diabetes. Fifty plants are reported to be used in the region for the treatment of diabetes. The five most common herbal medicines used were Salvia officinalis, Trigonella foenum-graecum, Olea europaea, Artemisia herba-alba and Origanum vulgare [15].

A study by Laadim et al. [12] in Sidi Slimane (northwestern Morocco) reported that 59 plant species were cited by 700 diabetic patients for management of diabetes. Five plants, Trigonella foenum-graecum, Oreganum vulgare, Salvia officinalis, Marrubium vulgare and Olea europaea, were most used. The survey revealed that seeds and leaves are the part of the plant most often used in herbal preparations.

In an ethnobotanical survey by Bousta et al. [16], 22 species of plants belonging to 19 families were reported for the treatment of diabetes in the Middle-Atlas region of Morocco (Sefrou region). The most prominent plants reported were Olea europaea, Salvia officinalis, Trigonella foenum-graecum, Euphorbia officinarum subsp. echinus, Globularia alypum, Coriandrum sativum. Respondents said that they inherited the knowledge of their practices from their parents, traditional healers, some books and nowadays from television programs.

Also in the Central Middle Atlas an ethnobotanical study identified 76 medicinal plants, divided into 67 genus and 40 families. Fourteen plants are reported for the first time intraditional treatment of diabetes in Morocco. They are: Pistacia atlantica, Anacyclus pyrethrum, Ptilotrichum spinosum, Cistus albidus, Juniperus thurifera, Thymus algeriensis, Thymus munbyanus, Thymus zygis, Abelmoschus esculentus, Fraxinus angustifolia, Sorghum bicolor and Eriobotrya japonica [13].

To inventory the medicinal plants used in traditional medicine to treat diabetes in the Tizi n' Test Region (Taroudant Province), a survey was carried using semistructured and structured questionnaires. Thirty-nine plant species belonging to 24 botanical families were recorded for the treatment of diabetes. The most important species were Artemisia herba-alba, Cistus creticus, Lavandula maroccana, Salvia officinalis and Olea europaea. Leaves were the parts predominantly used and decoction was the most common method to prepare the formulations [26].

Another ethnobotanical survey among the local population in the region of $\mathrm{Al} \mathrm{Haouz-Rhamna} \mathrm{(central}$ Morocco) reported that a total of 150 plant species belonging to 54 families were used for the treatment of diabetes in the area. Among these species recorded 18 are cited for the first time in the region as an antidiabetic plants namely: Chamaerops humilis, Cladanthus arabicus, Centaurea maroccana, Matricaria chamomilla, Tanacetum vulgare, Diplotaxis pitardiana, Berberis vulgaris subsp. australis, Corrigiola litoralis subsp. telephiifolia, Cistus laurifolius, Quercus coccifera, Ballota hirsuta, Buxus balearica, Lavandula stoechas, Ocimum basilicum, Thymus satureioides, Ruta montana, Taxus baccata and Thymelaea virgata [17].

In the region of Tan-Tan (South of Morocco), a survey reported that 129 medicinal species belonging to $53 \mathrm{fam}$ ilies were cited by 350 people for the treatment of diabetes with the dominance of the most represented families in the flora of Morocco. Some of the inventoried plant species are endemic to the Sahara such as Cynomorium coccineum, Atriplex halimus and Salsola tetragona, but others are toxic including Aristolochia fontanesii, Euphorbia officinarum and Nerium oleander [18].

In the region of Meknes-Tafilalet (North-central Morocco), an ethnobotanical study was undertaken in order to inventory the main medicinal plants used in folk medicine to treat diabetes. In this region, the most frequently used plants include Allium cepa, Artemisia herba-alba and Trigonella foenum graecum [19]. Also in the North central region of Morocco (Fez-Boulemane), an ethnobotanical study reported that 90 medicinal species are used in the treatment of diabetes, hypertension 
and renal diseases. Among these species, 9 plants are toxic at high doses. For diabetes, 54 plants were cited, of which the most cited were: Artemesia herba alba, Trigonella foenum-graecum and Tetraena gaetula [22].

In the Errachidia province (South-eastern Morocco), a survey was carried out to catalog the plants traditionally used in the treatment of hypertension and diabetes mellitus. The authors have inventoried 64 species belonging to 33 families, of which 45 plants were used in the treatment of diabetes. The most frequently cited plant species by the local population for management of diabetes are Ajuga iva, Allium cepa, Artemisia herba-alba, Carum carvi, Lepidium sativum, Nigella sativa, Olea europaea, Peganum harmala, Phoenix dactylifera, Rosmarinus officinalis, and Tetraena gaetula [20]. Also in south-eastern Morocco (Tafilalet region), an ethnobotanical study identified 92 medicinal plants used in the treatment of diabetes mellitus, hypertension and cardiac diseases. The most frequently cited medicinal plants used for their antidiabetic effects were Ammi visnaga, Artemesia herba-alba, Trigonella foeniculum-granum, Marrubium vulgare, Nigella sativa, Globularia alypum, Allium sativum, Olea europaea, Citrullus colocynthis, Aloe succotrina, Artemisia absinthium, Rosmarinus officinalis, Thymus vulgaris, Eucalyptus globulus, Mentha pulegium, Myrtus communis, Linum usitatissimum and Carum carvi [21].

\section{Pharmacological and toxicological studies}

Among 255 plant species being used, 120 plants have neither been explored experimentally for antidiabetic activity. They are: Mesembryanthemum theurkauffii, Salsola tetragona, Searsia albida, Searsia tripartita, Eryngium ilicifolium, Pastinaca sativa, Ptychotis verticillata, Ridolfia segetum, Apteranthes europaea, Periploca laevigata subsp. Angustifolia, Aristolochia fontanesii, Agave americana, Asparagus albus, Achillea odorata, Antennaria dioica, Anvillea garcinii subsp. radiata, Artemisia abrotanum, Artemisia atlantica, Artemisia mesatlantica, Artemisia reptans, Centaurea maroccana, Cladanthus arabicus, Cynara cardunculus, Dittrichia viscosa, Echinops spinosissimus, Inula conyza, Inula helenium, Launaea arborescens, Pallenis spinosa, Scolymus hispanicus, Scorzonera undulata, Sonchus arvensis, Sonchus tenerrimus, Tanacetum vulgare, Berberis vulgaris subsp. australis, Diplotaxis pitardiana, Eruca vesicaria, Ptilotrichum spinosum, Buxus balearica, Maerua crassifolia, Herniaria glabra, Silene vivianii, Cistus albidus, Cistus creticus, Cistus salviifolius, Androcymbium gramineum, Juniperus thurifera, Tetraclinis articulata, Cynomorium coccineum, Bolboschoenus maritimus, Dracaena draco subsp. ajgal, Ephedra alata, Ephedra altissima, Euphorbia officinarum subsp. echinus, Euphorbia officinarum subsp. officinarum, Hammada scoparia,
Euphorbia resinifera, Mercurialis annua, Anagyris foetida, Ceratonia siliqua, Cicer arietinum, Lupinus angustifolius, Lupinus luteus, Ononis natrix, Ononis tournefortii, Retama sphaerocarpa, Vicia faba, Vicia sativa, Quercus coccifera, Juncus maritimus, Ballota hirsuta, Clinopodium alpinum, Clinopodium nepeta subsp. glandulosum, Lavandula dentata, Lavandula maroccana, Lavandula multifida, Mentha pulegium, Mentha spicata, Origanum compactum, Origanum majorana, Origanum vulgare, Thymus algeriensis, Thymus munbyanus, Thymus zygis, Corrigiola litoralis subsp. telephiifolia, Fumaria officinalis, Papaver rhoeas, Globularia repens, Limonium sinuatum, Avena sativa, Castellia tuberculosa, Panicum miliaceum, Panicum turgidum, Polypogon monspeliensis, Triticum durum, Emex spinosa, Fragaria vesca, Rubus vulgaris, Rubia tinctorum, Salix alba, Illicium verum, Taxus baccata, Thymelaea tartonraira, Thymelaea virgata, Aloysia citriodora, Aloe succotrina, Asphodelus microcarpus, Mesembryanthemum theurkauffii, Cladanthus scariosus, Paronychia argentea, Ephedra fragilis, Glycyrrhiza glabra, Origanum elongatum, Thymus broussonetii, Avena sterilis, Lolium perenne, Malus communis, Verbena officinalis, Asphodelus tenuifolius and Tetraena gaetula. It is essential to study the effects of unexplored plant species on diabetes in more detail and to identify the active components and especially to study the mechanisms of action of these plant extracts, in order to obtain further data on the pharmacological effects of these plants.

Despite the therapeutic effects of medicinal plants, excessive consumption of some of the inventoried plants might lead to harmful effects which are related to a variety of causes. To avoid danger to patients, prudent use as well as safety precautions is required, such as using lower doses. The main toxic plants are, Citrullus colocynthis [32], Datura stramonium [33], Euphorbia officinarum [34], Myristica fragrans [35], Artemisia herba alba [36], Peganum harmala [37], Ricinus communis [38], Tetraena gaetula [39], Nigella sativa [40] and Nerium oleander [32]. Despite their toxic properties, patients do not suffer any adverse consequences. This indicates that the patients or the provider of the plants are skilled in recognizing the potential for toxicity and taking the appropriate precautions.

Of all medicinal plants reported in this study, 137 medicinal plants have been documented to demonstrate a potent anti-diabetic effect in vitro or in vivo or in clinical studies. We present in Table 2 pharmacological studies which have investigated directly or indirectly medicinal plants used in Morocco to treat diabetes. Trigonella foenum-graecum, Artemesia herba-alba, Nigella sativa, Olea europaea, Allium cepa and Marrubium vulgare were the most frequently used plants to treat diabetes based on number of citations. These plants are discussed in detail below. 


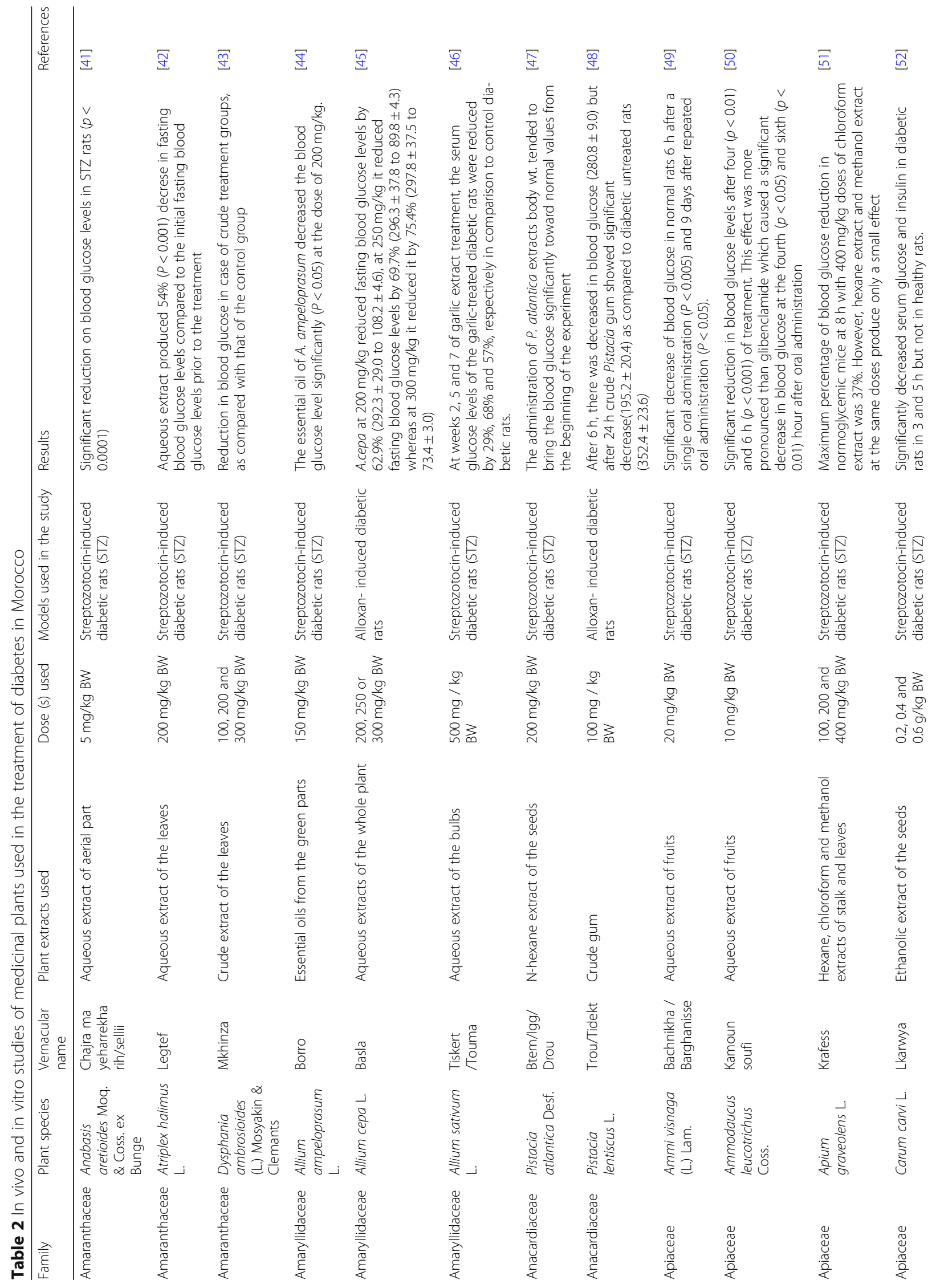




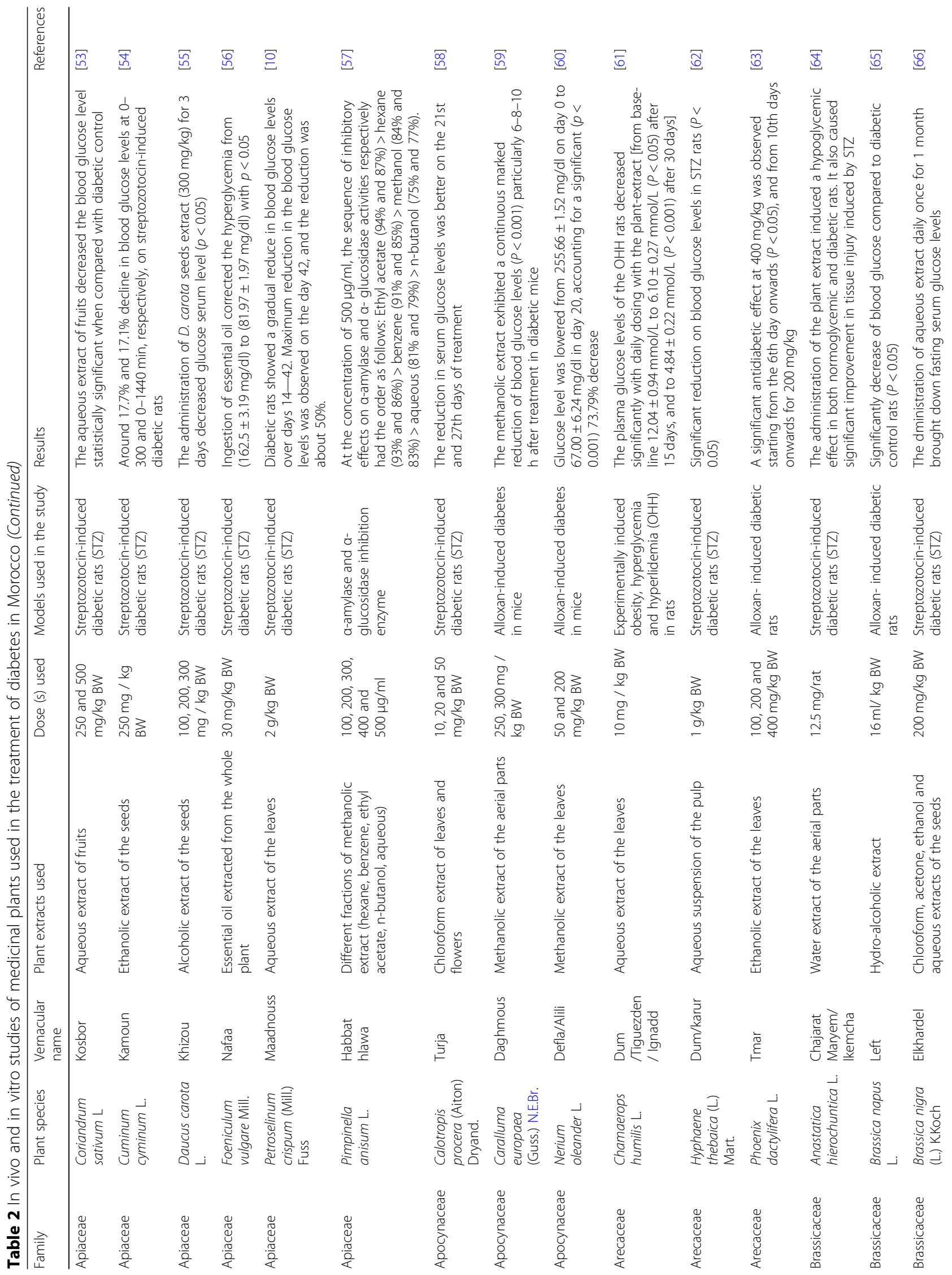




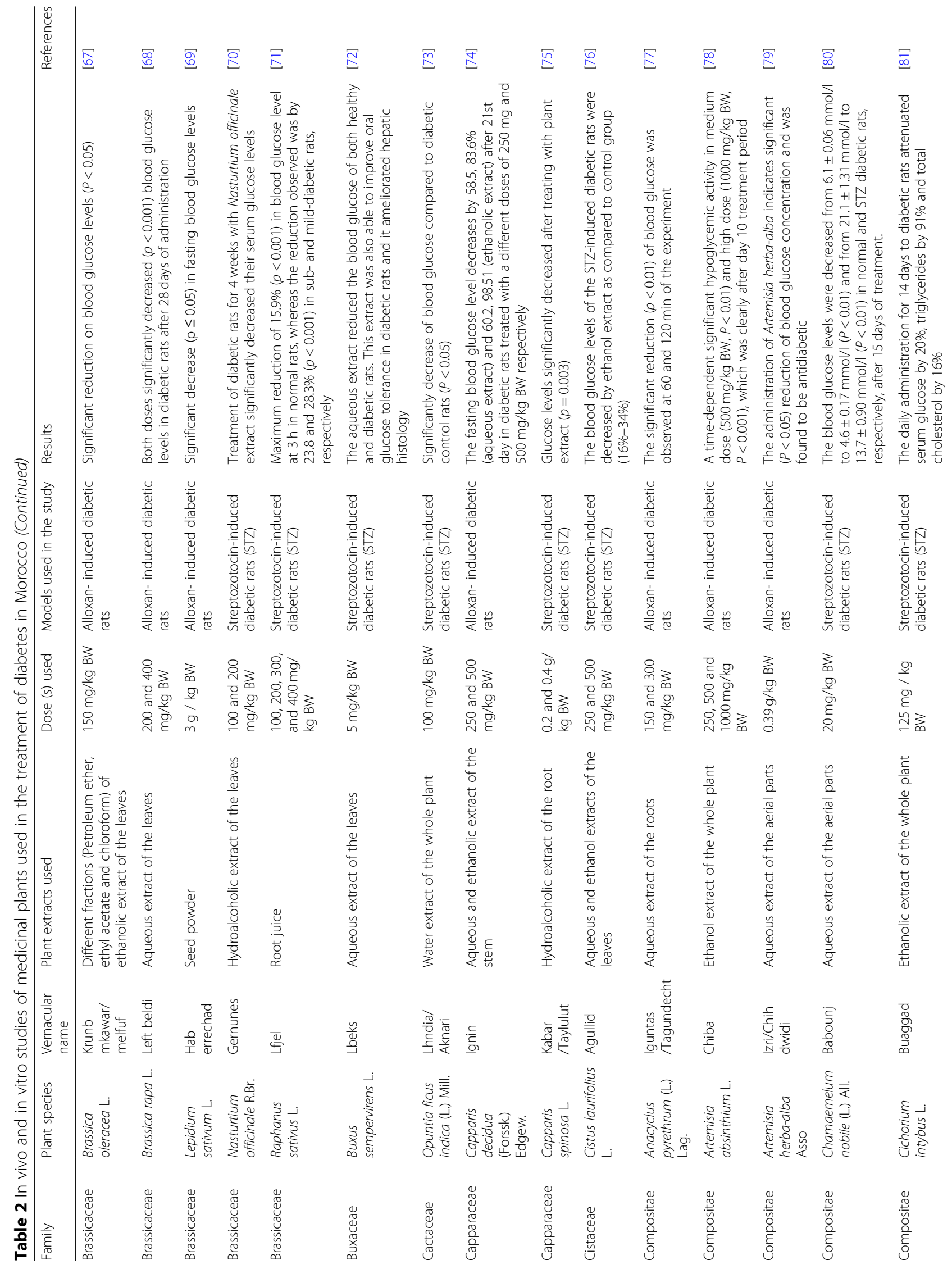




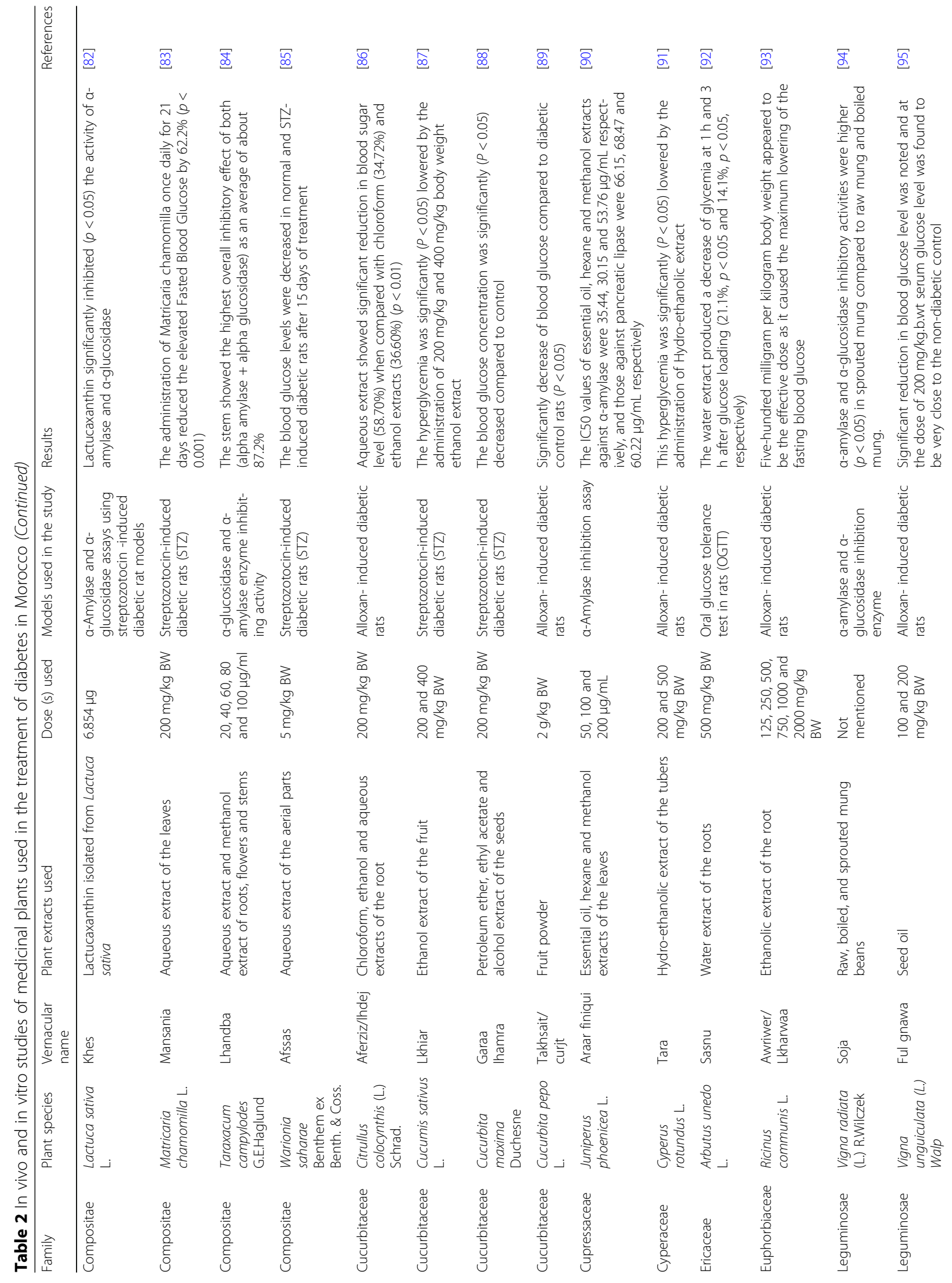




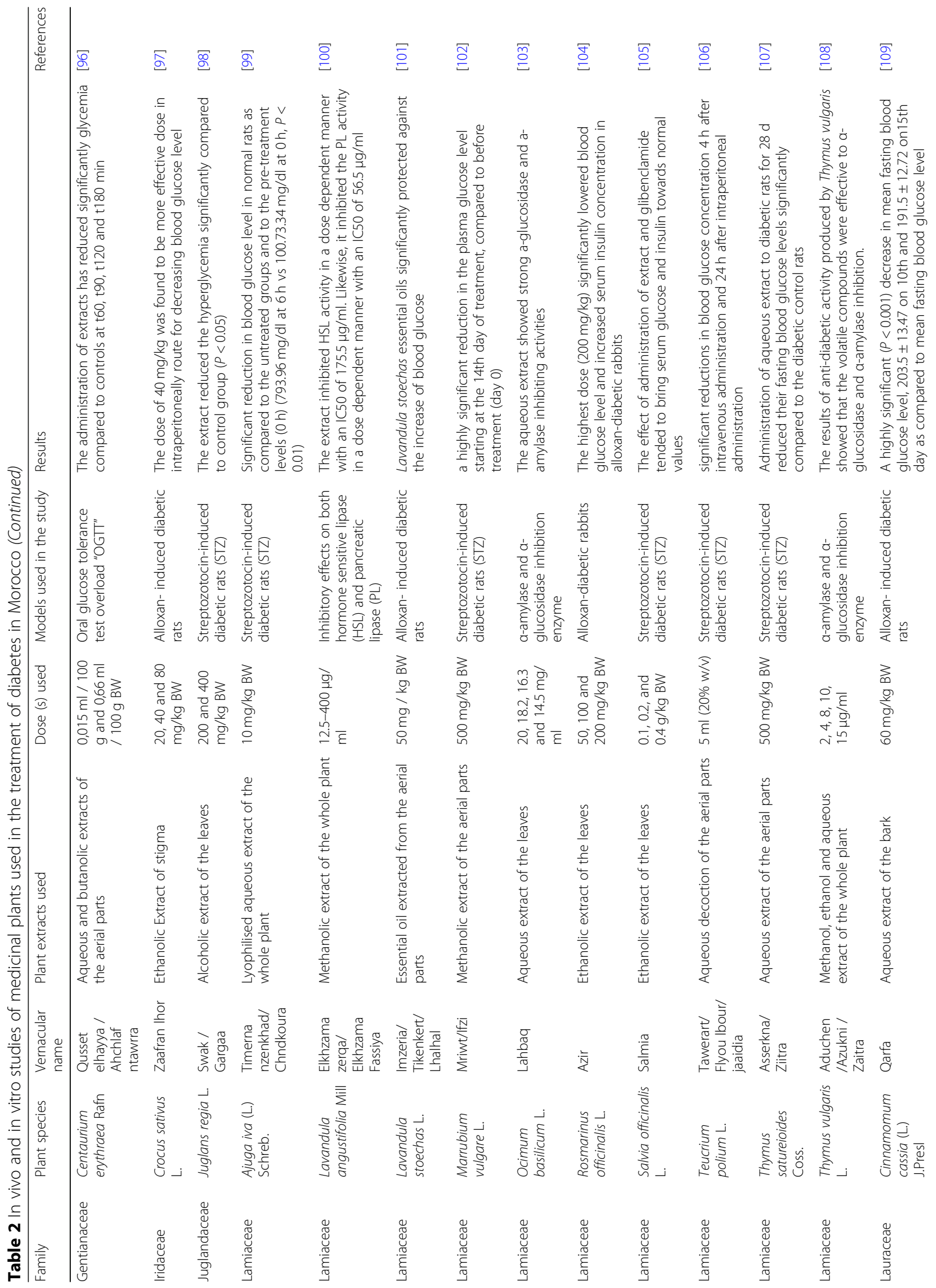




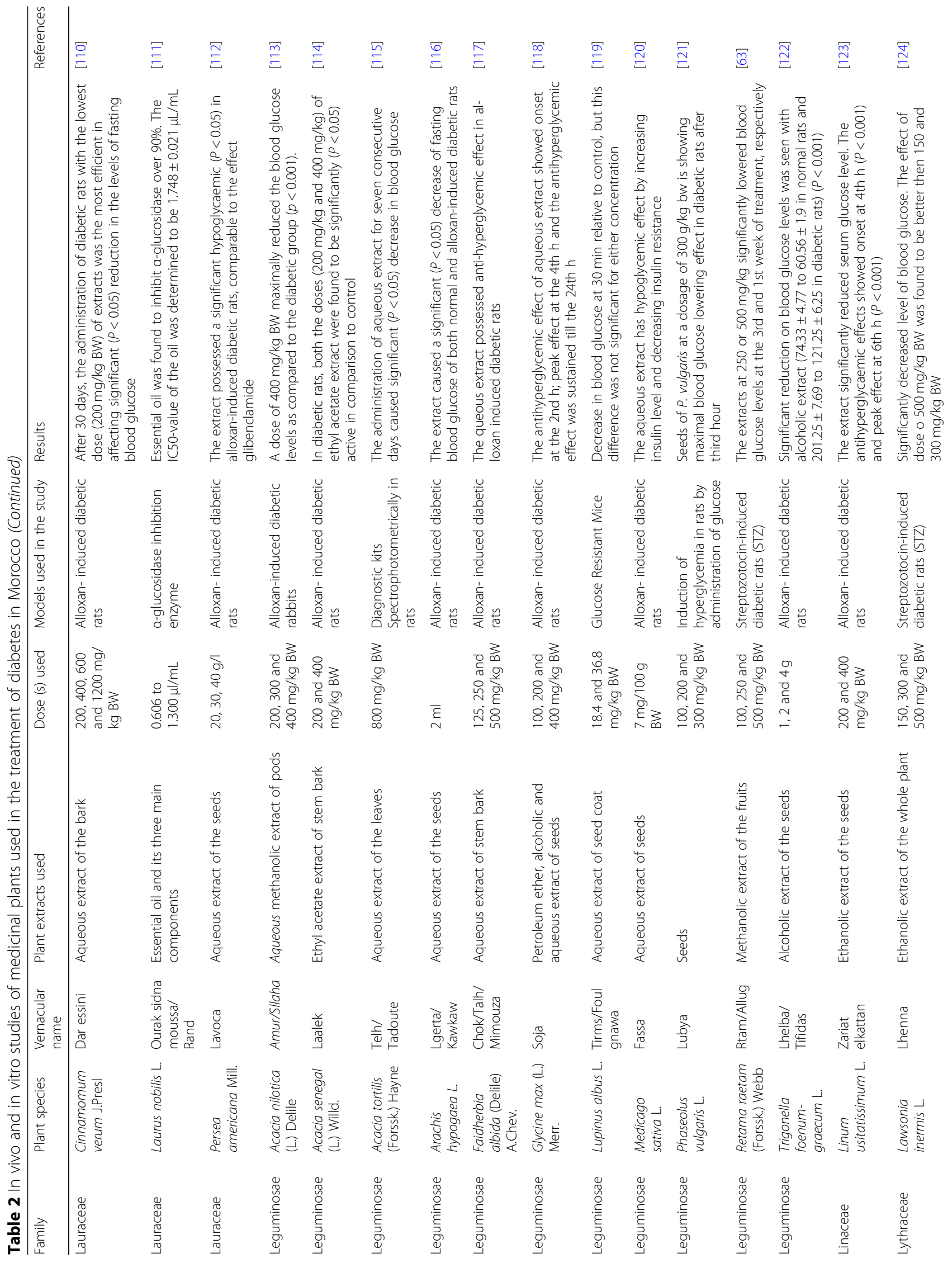




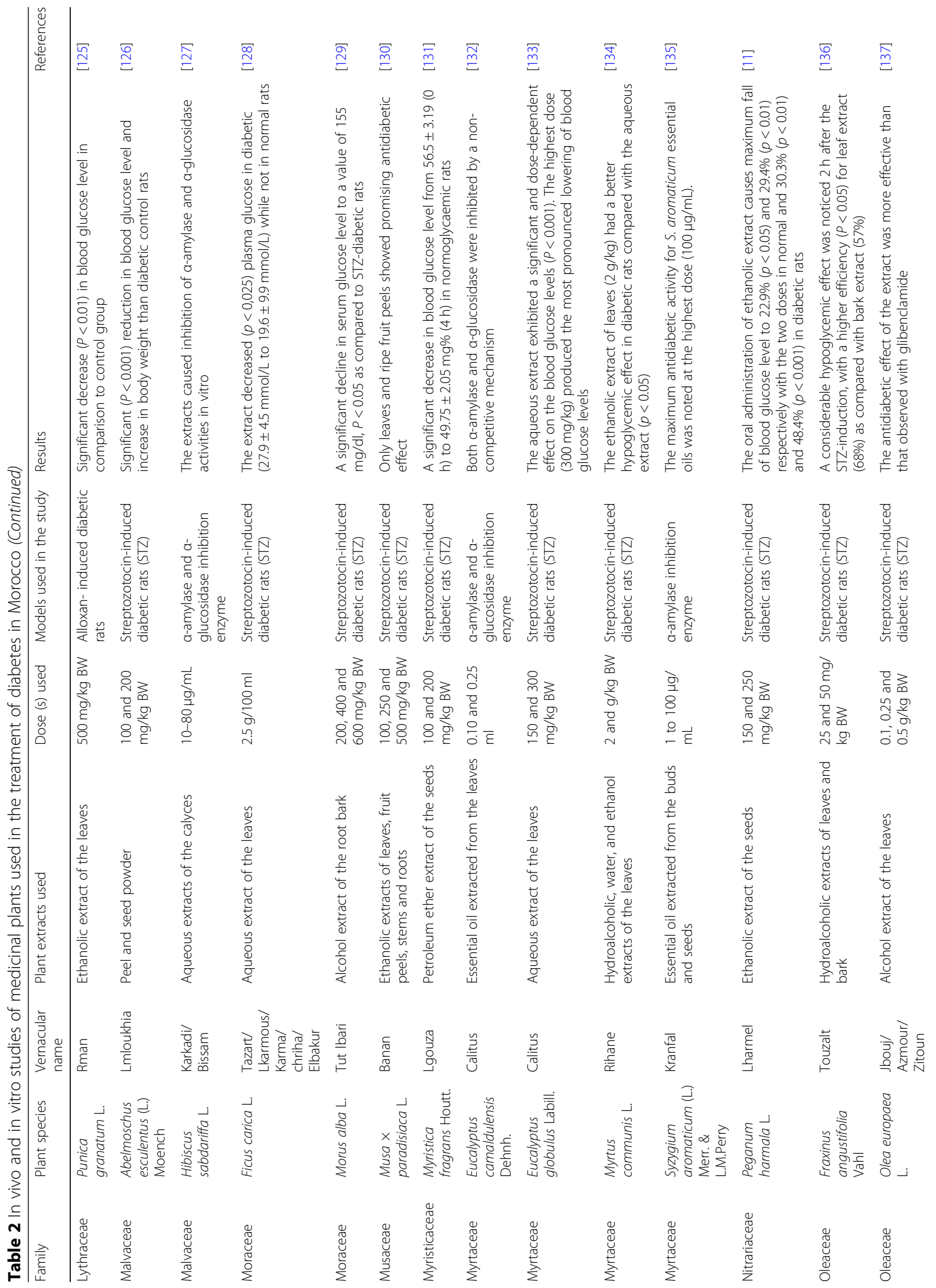




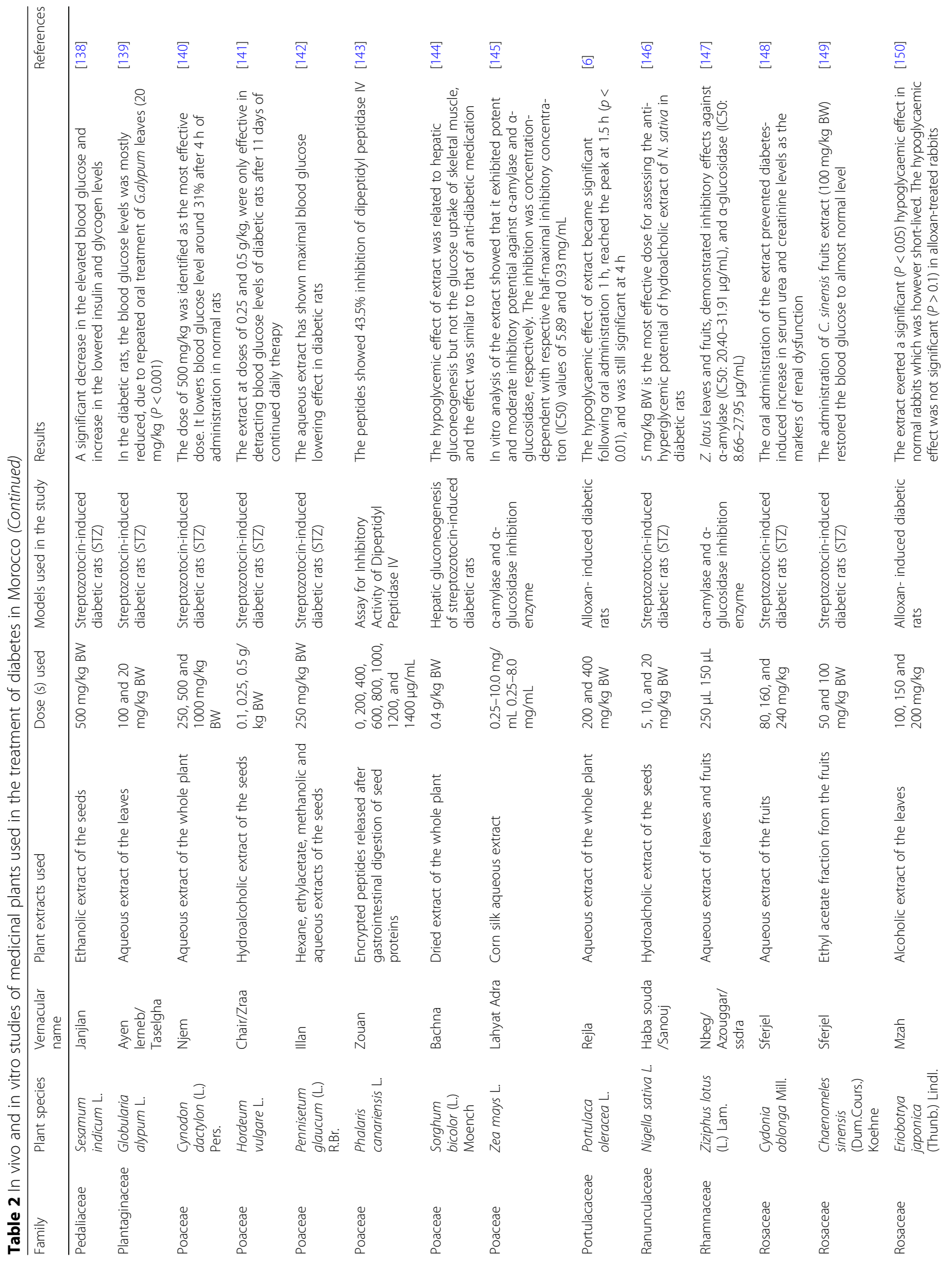




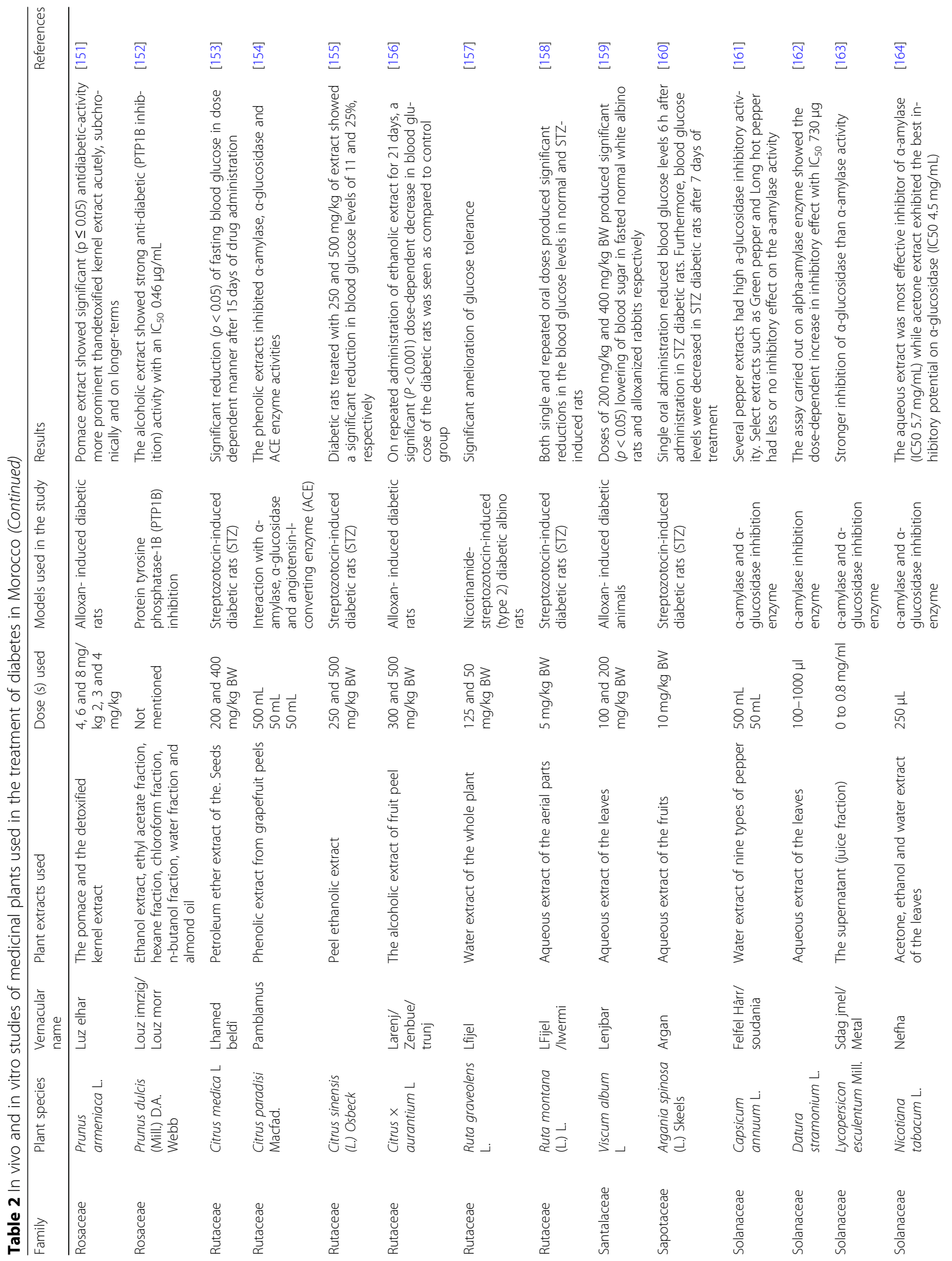




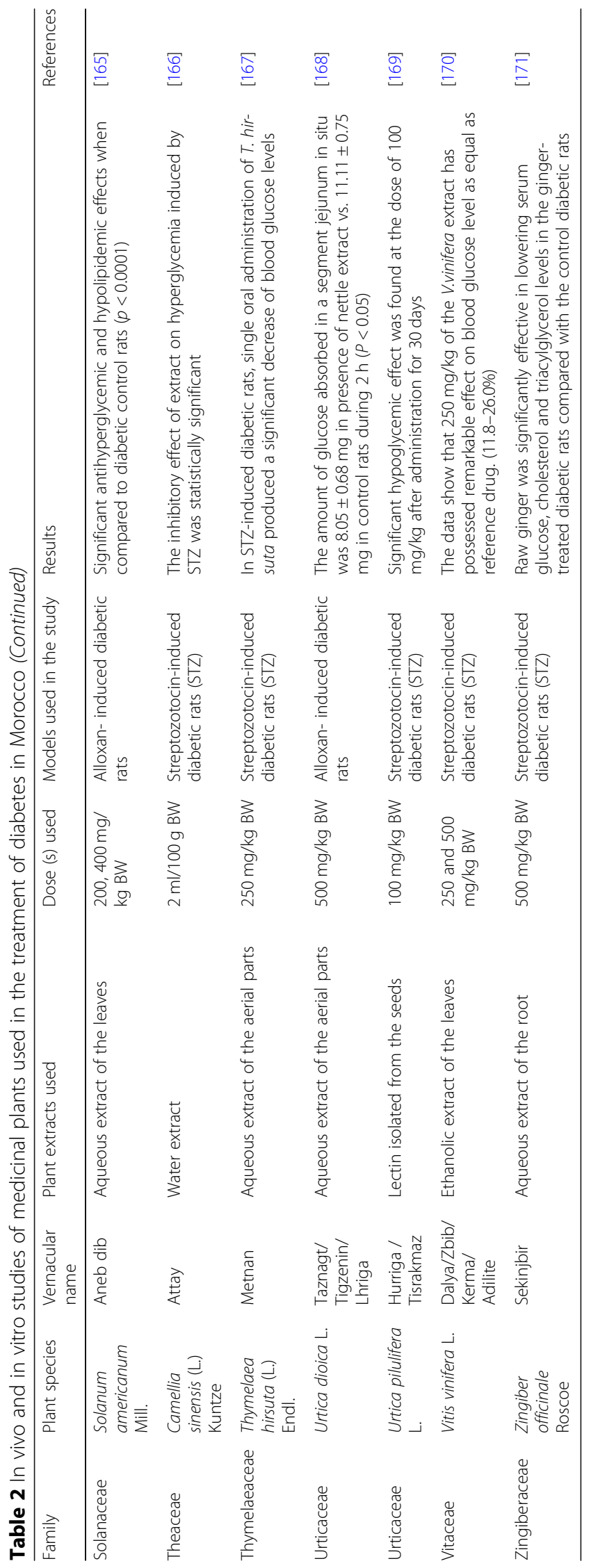


Plants used most frequently for the treatment of diabetes in Morocco

\section{Trigonella foenum-graecum $L$.}

Trigonella foenum-graecum L. (Fenugreek), is an annual plant, in the family Leguminosae, extensively cultivated in many countries (Morocco, Egypt, China, India, Ethiopia,Turkey, Ukraine, Greece, etc.) [172]. Apart from the usage as an edible species and spice herb, fenugreek is known for its nutraceutical, medicinal, and pharmaceutical features. It has been reported that fenugreek is a valuable medicinal plant with potential for curing abscesses, wounds, arthritis, bronchitis, digestive disorders, fever and sinusitis. It is cited as used in the treatment of diabetes by Moroccan ethnobotanical studies [2, 12-23]. Fenugreek is known to have several pharmacological effects such as antidiabetic, lactation aid, antibacterial, gastric stimulant, for anorexia, galactogogue, hepatoprotective effect, anticancer, anticarcinogenic, hypocholesterolemic, antioxidant, and immunological activities. Fenugreek is an excellent source of neutral detergent fiber, proteins, vitamins as well as chemical constituents [172-176].

Hypoglycaemic activity of alcoholic extract of seeds of Trigonella foenum-graecum was tested in both normal and alloxan-induced diabetic rats. Significant decrease in glycaemia was seen with alcoholic extract $(74.33 \pm 4.77$ to $60.56 \pm 1.9$ in normal rats and $201.25 \pm 7.69$ to $121.25 \pm 6.25$ in diabetic rats $)(P<0.001)$ [122].

Fenugreek water seed extract was found to increase the body weight and decrease the fasting blood glucose in streptozocin-induced diabetic rats [177]. Similar results were obtained in the study done by Abdelatif et al. [178] who found that there was a weight gain in fenugreek treated rabbits as compared to the group that received only alloxan monohydrate. Plasma glucose level was reduced as compared to the alloxan monohydrate induced diabetic rabbits.

Administration of Trigonella foenum-graecum seeds ( 2.5 and $5 \mathrm{~g}$ ) for 4 weeks to sixty newly diagnosed diabetic patients, improved blood glucose level in dose-dependent. The medium dose $(5 \mathrm{~g})$ of fenugreek seeds reduces significantly the glycemia (8.83 vs $6.45, p<0.05)$ [179].

An active compound $\left(\mathrm{G}_{\mathrm{II}}\right)$, isolated from water extract of seeds of fenugreek orally administered to the subdiabetic and mild diabetic rabbits, was capable of reduce blood glucose in glucose tolerance test [180].

\section{Artemisia herba-alba Asso}

Artemisia herba-alba Asso. (Compositae), known as the desert wormwood (Shih in arabic), is a dwarf, semi shrub, strongly aromatic herb, growing widely in arid and semiarid areas of the Mediterranean basin and in Western Asia spreading into middle east, north-western Himalayas and India $[181,182]$. This species is used medicinally to treat various diseases such as hypertension, diarrhoea, diabetes, colds, muscle tensions, coughing, intestinal distress and fever [183, 184]. It is cited as used in the treatment of diabetes in Morocco [2, 12, 14-23].

Numerous scientists have showed various biological and pharmacological effects in Artemisia herba-alba essential oils, especially antibacterial, antispasmodic, antidiabetic, antioxidant, leishmanicidal, and antifungal properties [185-188]. In essential oils, monoterpenes were the major components, essentially $\alpha$ - and $\beta$-thujones, camphor, 1,8-cineole and chrysanthenyl derivatives, but sesquiterpenes also were found in some countries [189-192].

Taştekin et al. [79] reported the hypoglycaemic effect of aqueous extract of Artemisia herba-alba in alloxaninduced diabetic rats. Aqueous extract of the aerial parts at the dose of $0.39 \mathrm{~g} / \mathrm{kg} \mathrm{BW}$ (body weight) significantly reduced $(P<0.05)$ blood glucose concentration. Its hypoglycaemic effect was comparable with that of insulin and repaglinide.

In vitro screening of hypoglycemic activity of Artemisia herba-alba using $\alpha$-amylase inhibition technique emphasized its activity in hypoglycemic remedy. The $70 \%$ ethyl alcohol extract and mucilage of $70 \%$ ethyl alcohol inhibited the activity of $\alpha$-amylase by $11 \%$ and $2 \%$ respectively [193].

A dose of $2 \mathrm{~g} / \mathrm{kg}$ of hydro-alcoholic extracts of Artemisia herba-alba, orally administered daily for 18 weeks, to male mice fed high fat diet, significantly decreased the blood glucose level $(143.8 \pm 23.9$ vs. $229.0 \pm 20.8 \mathrm{mg} / \mathrm{dl}$, $p<0.05)$, triglyceride $(18.9 \pm 11.1$ vs. $62.8 \pm 18.3 \mathrm{mg} / \mathrm{dl}$, $p<0.05)$, total cholesterol $(1.2 \pm 0.1$ vs. $1.8 \pm 1.1 \mathrm{~g} / \mathrm{L}, p<$ $0.05)$ and serum insulin concentrations $(1.7 \pm 0.7$ vs. $3.3 \pm 14.3 \mathrm{ng} / \mathrm{ml}, p<0.05)$ [194].

\section{Nigella sativa $L$.}

Nigella sativa L. (Family Ranunculaceae), commonly known as black seed or Kalonji seed, is widely grown medicinal plant throughout the world. Seeds and their oil have many food and medicinal uses $[195,196]$. It has received attention for its potential application in the treatment and prevention of a number of diseases, such as fever, asthma, diarrhoea, dyslipidaemia, common cold, headache, warts, stings of scorpions, bites of snake and rheumatic diseases [197-199]. Moreover, a variety of secondary metabolites has been identified in this species, such as fixed oil, protein, alkaloid, saponin, isochinoline alkaloids (nigellimin and nigellimin-N-oxide), pyrazol alkaloids (nigellidin and nigellicin), thymoquinone, $\mathrm{p}$ cymene, pinene, dithymoquinone, thymohydroquinone, carvacrol, carvone, limonene, 4-terpineol and citronellol $[195,196]$. It has been reported to possess potent antiinflammatory, anti-hyperlipidemic, anti-microbial, anticancer, anti-oxidant, anti-diabetic, anti-hypertensive, hepatoprotective, antiparasitic, analgesic, anti-nociceptive, anti-ulcer, anti-histaminic and wound healing activities 
[196, 200]. Nigella sativa used in Morocco in the treatment of diabetes [2, 13-23].

Alimohammadi et al. [146] reported the hypoglycaemic effect of hydroalcholic extract of Nigella sativa seeds (5, 10 , and $20 \mathrm{mg} / \mathrm{kg} \mathrm{BW}$ ) in streptozotocin-induced diabetic rats (STZ). Nigella sativa at $5 \mathrm{mg} / \mathrm{kg}$ reduced blood glucose concentration level from $(565.4 \pm 30.9 \mathrm{mg} / \mathrm{dl})$ to $(323.2 \pm 32.2 \mathrm{mg} / \mathrm{dl})$, at $10 \mathrm{mg} / \mathrm{kg}$ it reduced blood glucose concentration level from $(565.4 \pm 30.9 \mathrm{mg} / \mathrm{dl})$ to $(513.2 \pm$ $42.7 \mathrm{mg} / \mathrm{dl}$ ), whereas at $20 \mathrm{mg} / \mathrm{kg}$ it reduced it from $(565.4 \pm 30.9 \mathrm{mg} / \mathrm{dl})$ to $(517.6 \pm 27.3 \mathrm{mg} / \mathrm{dl})$.

The antidiabetic activity of methanolic crude extract and the commercial oil of Nigella sativa seeds in alloxan- induced diabetic rats was examined by Houcher et al. [201]. Administration of the crude methanolic extract at a dose of $810 \mathrm{mg} / \mathrm{kg} /$ day and the oil at a dose of $2.5 \mathrm{ml} / \mathrm{kg} /$ day decreased significantly the blood glucose (decreases of 58.09 and $73.27 \%$ respectively) after 10 days of treatment.

Administration of the volatile oil extracted from $\mathrm{Ni}$ gella sativa seeds experimentally caused a significant decrease in blood glucose level in alloxan-diabetic rabbits (2\% and $21 \%$ decreases in the fasting glucose levels at the $4 \mathrm{~h}$ and the $6 \mathrm{~h}$ time intervals, respectively) [202].

\section{Olea europaea $L$.}

Olea europaea L. (Olive) belongs to the plant family Oleaceae, is a small tree that produces the olive fruit, cultivated in the coastal areas of the eastern Mediterranean basin, the contiguous coastal areas of southeastern Europe, northern Iran at the south end of the Caspian Sea, western Asia, and northern Africa [203, 204]. Phytochemical investigations on Olea europaea have revealed the presence of various phytochemicals including phenolic compounds (oleuropein, hydroxytyrosol, verbascoside, apigenin-7glucoside and luteolin-7-glucoside), flavonoids, secoiridoids, triterpenes, biophenols, benzoic acid derivatives, xylitol, sterols, isochromans and sugars [204, 205]. Olea europaea has a variety of medicinal properties and traditional uses. The plant has been used to treat diabetes, high blood pressure, cardiovascular diseases, influenza, chronic fatigue syndrome, to support time of recovery, immune system, stomach and intestinal diseases, common cold, malaria, dengue, severe diarrhoea, respiratory and urinary tract infections, and as mouth cleanser [204, 206]. Various biological activities of Olea europaea have been extensively studied like antihypertensive, analgesic, antimicrobial, anticancer, antihyperglycemic, antidiabetic, anticonvulsant, antioxidant, anti-inflammatory, immunomodulatory, antiviral, antinociceptive, and gastroprotective activities [203, 204]. It is cited in the ethnobotanical surveys that the plant is used in the treatment of diabetes in Morocco [2, 12, 13, 15-23].
Eidi et al. [137] showed the antidiabetic effect of alcohol extract of Olea europaea leaves in normal and streptozotocin-induced diabetic rats. Rats were divided into nine groups, group1: normal control rats, groups 2, 3, 4: normal ratstreated with Olea europaea, group 5: diabetic control rats, group 6, 7, 8: diabetic rats treated with Olea europaea, group 9: diabetic rats treated with glibenclamide. The administration of extract at a dose of $0.1,0.25$ and $0.5 \mathrm{~g} / \mathrm{kg} \mathrm{BW}$ for 14 days significantly decreased the blood glucose in diabetic rats $(p<0.05)$.

Another study was conducted to check the antidiabetic potential of oleanolic acid (an agonist for TGR5), isolated from Olea europeaea leaves in mice fed with a high fat diet. Oleanolic acid cause a decrease in blood glucose concentration and insulin levels and it enhances glucose tolerance [207].

Several other studies demonstrated the antidiabetic effect of Olea europaea in streptozotocin diabetic rats [208-214], in alloxan diabetic rats [215-219], in alloxan diabetic rabbits [215], in human diabetic subjects [209] and in vitro $\alpha$-amylase and $\alpha$-glucosidase inhibitory activities [220, 221].

\section{Allium cepa $L$.}

Allium cepa L., commonly known as onion, botanically classified under the Amaryllidaceae family, is a biennial plant widely cultivated around the world. Onion is utilized as both vegetable and flavouring [222, 223].

According to traditional medicine experts, Onion is one of the oldest medicinal plants used to relieve several ailments including metabolic disease, wound healer, pneumonia fighters, digestive problems, skin diseases and insect bites, diabetes and asthma [224, 225]. Allium cepa used in Morocco in the treatment of diabetes [2, 12-22].

There are many chemical constituents in Allium cepa, including vitamins and minerals. Moreover, a variety of secondary metabolites has been identified in this species, such as phenolic compounds (particularly ferulic acid, gallic acid, protocatechuic acid, quercetin, and kaempferol), flavonoids (particularly quercetin aglycon, quercetin-3,4'-diglucoside, quercetin-4' -monoglucoside, quercetin-3-monoglucoside, quercetin 3-glycosides, delphinidin 3,5-diglycosides, quercetin 3,7,4'-triglucoside, quercetin 7,4'-diglucoside, quercetin 3,4'-diglucoside and isorhamnetin 3,4'-diglucoside), phytosterols and saponins [226-230].

Recent studies have shown that this plant has different biological properties, such as hypolipidemic, antihypertensive, antimicrobial, antioxidant, analgesic, antiinflammatory, immunoprotective, and anti-diabetic effects [222, 224].

The hypoglycemic effect of Allium cepa was confirmed by aqueous extracts of the whole plant in alloxan (150 $\mathrm{mg} / \mathrm{Kg} \mathrm{BW}$ ) rat model of diabetes. Allium cepa at 200 $\mathrm{mg} / \mathrm{kg}$ reduced fasting blood glucose levels by $62.9 \%$ 
$(292.3 \pm 29.0$ to $108.2 \pm 4.6)$, at $250 \mathrm{mg} / \mathrm{kg}$ it reduced fasting blood glucose levels by $69.7(296.3 \pm 37.8$ to $89.8 \pm 4.3$ ) whereas at $300 \mathrm{mg} / \mathrm{kg}$ it reduced it by $75.4 \%$ $(297.8 \pm 37.5$ to $73.4 \pm 3.0)$ [45].

Another study showed the hypoglycemic effect of onion juice on alloxan-induced diabetic rats. After 4 week treatment of onion juice $(1 \mathrm{ml} / 100 \mathrm{~g}$ body weight), significant anti-hyperglycaemic effect were observed in treated rats [231].

The antidiabetic effect of $200 \mathrm{mg} / \mathrm{kg}$ body weight for 60 days of S-methyl cysteine sulfoxide (SMCS) isolated from Allium cepa was studied and compared in alloxaninduced diabetic rats. Results suggested that the administration of SMCS reduced blood glucose level [232].

In another experiment conducted by El-Soud and Khalil [233], they found that treatment with onion essential oil caused a significant decrease in serum lipids, lipid peroxide formation, blood glucose and increase in serum insulin in streptozotocin induced diabetic albino rats.

\section{Marrubium vulgare $L$.}

Marrubium vulgare L. is a perennial herb of the Lamiaceae family, popularly known as white horehound. This aromatic plant is native to the Mediterranean Sea region can be found in many temperate regions of Europe, North of Africa and Asia [234, 235]. It could be used to cure and treat several diseases, such as laryngitis, bronchitis, skin abrasions, wounds, bronchial asthma, nonproductive cough, hepatic affections and in phthisis $[235,236]$. Marrubium vulgare is rich in phytochemicals like amino acids, polysaccharides, tannins, phenols, flavonoids, alkaloids, steroids, lactones and, in particular, terpenes [237, 238]. The plant is reported to possess hypoglycemic, vasorelaxant, analgesic, antioxidant, antierdematogenic, anti-inflammatory, vasodilator and antihypertensive properties [236, 238]. Horehound used in Morocco in the treatment of diabetes [2, 12-19, 21-23].

Elberry et al. [102] showed that methanolic extract of the aerial parts of Marrubium vulgare can have beneficial effect in diabetes and its complication. They showed on a streptozotocin rat model the antidiabetic effect of a daily single oral dose of $500 \mathrm{mg} / \mathrm{kg} /$ day of Marrubium vulgare for 28 days. The methanolic extract produced a significant decrease in blood glucose starting on the second week and a significant increase in plasma insulin and tissue glycogen contents.

The administration of an aqueous extract from aerial parts infusion at dose 100,200 and $300 \mathrm{mg} / \mathrm{kg} \mathrm{BW}$ to alloxan-induced diabetic rats decreased significantly the blood glucose level in a dose dependent manner (a decrease by $50 \%$ for the dose $100 \mathrm{mg} / \mathrm{kg}$ and more than $60 \%$ for doses 200 and $300 \mathrm{mg} / \mathrm{kg}$ ) [239].

The antidiabetic activity of various ethanolic extracts (root, leaf and stem) from Marrubium vulgare on normoglycemic rats was examined by Vergara-Galicia et al. [240].The intragastric administration of both extracts (root and stem), at $100 \mathrm{mg} / \mathrm{kg} \mathrm{BW}$, significantly reduced blood glucose level in healthy rat. Furthermore, the increase in plasma glucose level was significantly suppressed by the ethanolic root extract after substrate oral administration.

\section{Conclusion}

Many Moroccan medicinal plants are reported to have blood sugar lowering properties that make them useful for the management of diabetes. We have reported 255 medicinal plants species belonging to 70 families in this study for the treatment of diabetes. Plants from the Compositae family were used most often in Morocco. The role of 135 Moroccan medicinal plants in the treatment of diabetes has been reviewed by several authors. However, 120 medicinal plants that are used for the treatment of diabetes in Morocco have not yet been studied in great detail for their antidiabetic properties. Furthermore, there are very few scientific reports of toxicological properties of these plants which would guarantee the safety of patients. In general, the literature search showed that some users of medicinal plants have only little information about toxic plants. In order to prevent the usage of toxic plants by the greater population, we have reported the major plants that have side effects according to toxicological documentations. Despite the therapeutic effects of medicinal plantsthey may have a toxicity risk which is related to a variety of causes including, contamination, misidentification, mistaken use of the wrong species, incorrect dosing and errors in use. Another problem, which may occur, is the possibility of adverse interaction between conventional medication and plant remedies. In conclusion, this review provides baseline data for plant species that have the potential antidiabetic activity and their associated knowledge in Morocco. However, many of the plant species mentioned require further pharmacological and clinical studies in order to validate any effective plant remedies to treat diabetes.

\section{Abbreviations}

BW: Body weight; DM: Diabetes mellitus; SMCS: S-methyl cysteine sulfoxide; STZ: Streptozotocin-induced diabetic rats

\section{Acknowledgements}

Not applicable.

Authors' contributions

El Manuscript preparation. FM Manuscript review. KC Supervising the whole work. All authors read and approved the final manuscript.

Funding

There is no funding for review article.

Availability of data and materials Not applicable. 


\section{Ethics approval and consent to participate}

Not applicable.

\section{Consent for publication}

Not applicable.

\section{Competing interests}

The authors declare that they have no competing interests.

Received: 26 October 2019 Accepted: 25 March 2020

Published online: 31 March 2020

\section{References}

1. Yaseen G, Ahmad M, Zafar M, Sultana S, Kayani S, Cetto AA, et al. Traditional management of diabetes in Pakistan: ethnobotanical investigation from traditional health practitioners. J Ethnopharmacol. 2015;174:91-117.

2. Barkaoui M, Katiri A, Boubaker H, Msanda F. Ethnobotanical survey of medicinal plants used in the traditional treatment of diabetes in Chtouka Ait Baha and Tiznit (Western anti-atlas), Morocco. J Ethnopharmacol. 2017; 198:338-50.

3. Giovannini P, Howes M-JR, Edwards SE. Medicinal plants used in the traditional management of diabetes and its sequelae in Central America: a review. J Ethnopharmacol. 2016;184:58-71.

4. Yagi SM, Yagi Al. Traditional medicinal plants used for the treatment of diabetes in the Sudan: a review. Afr J Pharm Pharmacol. 2018;12(3):27-40.

5. Surya S, Salam AD, Tomy DV, Carla B, Kumar RA, Sunil C. Diabetes mellitus and medicinal plants-a review. Asian Pac J Trop Dis. 2014;4(5):337-47.

6. Gao D, Li Q, Fan Y. Hypoglycemic effects and mechanisms of Portulaca oleracea L. in alloxan-induced diabetic rats. J Med Plant Res. 2010;4(19): 1996-2003.

7. Rahati S, Shahraki M, Arjomand G, Shahraki T. Food pattern, lifestyle and diabetes mellitus. Int J High Risk Behav Addict. 2014;3(1):e8725.

8. Mahomoodally MF, Mootoosamy A, Wambugu S. Traditional therapies used to manage diabetes and related complications in Mauritius: a comparative ethnoreligious study. Evid Based Complement Alternat Med. 2016;2016: 4523828.

9. Nazarian-Samani Z, Sewell RD, Lorigooini Z, Rafieian-Kopaei M. Medicinal plants with multiple effects on diabetes mellitus and its complications: a systematic review. Curr Diab Rep. 2018;18(10):72.

10. Yanardağ R, Bolkent Ş, Tabakoğlu-Oğuz A, Özsoy-Saçan Ö. Effects of Petroselinum crispum extract on pancreatic $B$ cells and blood glucose of streptozotocin-induced diabetic rats. Biol Pharm Bull. 2003;26(8):1206-10.

11. Singh AB, Chaturvedi J, Narender T, Srivastava AK. Preliminary studies on the hypoglycemic effect of Peganum harmala L. seeds ethanol extract on normal and streptozotocin induced diabetic rats. Indian J Clin Biochem. 2008;23(4):391-3.

12. Laadim M, Ouahidi M, Zidane L, El Hessni A, Ouichou A, Mesfioui A. Ethnopharmacological survey of plants used for the treatment of diabetes in the town of Sidi Slimane (Morocco). J Pharmacogn Phytother. 2017;9(6): 101-10.

13. Hachi M, Ouafae B, Hachi T, Imane B, Atmane R, Zidane L. Contribution to the ethnobotanical study of antidiabetic medicinal plants of the central middle atlas region (Morocco). Lazaroa. 2016;37:1.

14. Douira A, Zidane L. Étude ethnobotanique des plantes médicinales utilisées dans le traitement du diabète, et des maladies cardiaques dans la région d'Izarène (Nord du Maroc). J Appl Biosci. 2015;86(1):7940-56 [French with abstract in English].

15. Alami Z, Aynaou H, Alami B, Hdidou Y, Latrech H. Herbal medicines use among diabetic patients in oriental Morocco. J Pharmacogn Phytother. 2015;7(2):9-17

16. Bousta D, Boukhira S, Aafi A, Ghanmi M, El-Mansouri L. Ethnopharmacological study of anti-diabetic medicinal plants used in the middle-atlas region of Morocco (Sefrou region). Int J Pharm Res Health Sci. 2014;2(1):75-9

17. Benkhnigue O, Ben Akka F, Salhi S, Fadli M, Douira A, Zidane L. Catalogue des plantes médicinales utilisées dans le traitement du diabète dans la région d'Al Haouz-Rhamna (Maroc). J Anim Plant Sci. 2014;23:3539-68 [French with abstract in English].

18. Ghourri M, Zidane L, Douira A. Usage des plantes médicinales dans le traitement du Diabète Au Sahara marocain (Tan-Tan). J Anim Plant Sci. 2013;17(1):2388-411 [French with abstract in English].
19. El Amrani F, Rhallab A, Alaoui T, El Badaoui K, Chakir S. Étude ethnopharmacologique de quelques plantes utilisées dans le traitement du diabète dans la région de Meknès-Tafilalet (Maroc). Phytothérapie. 2010;8(3): 161-5 [French with abstract in English].

20. Tahraoui A, El-Hilaly J, Israili Z, Lyoussi B. Ethnopharmacological survey of plants used in the traditional treatment of hypertension and diabetes in South-Eastern Morocco (Errachidia province). J Ethnopharmacol. 2007;110(1):105-17.

21. Eddouks M, Maghrani M, Lemhadri A, Ouahidi M-L, Jouad H. Ethnopharmacological survey of medicinal plants used for the treatment of diabetes mellitus, hypertension and cardiac diseases in the south-east region of Morocco (Tafilalet). J Ethnopharmacol. 2002;82(2-3):97-103.

22. Jouad H, Haloui M, Rhiouani H, El Hilaly J, Eddouks M. Ethnobotanical survey of medicinal plants used for the treatment of diabetes, cardiac and renal diseases in the North Centre region of Morocco (fez-Boulemane). J Ethnopharmacol. 2001;77(2-3):175-82.

23. Ziyyat A, Legssyer A, Mekhfi H, Dassouli A, Serhrouchni M, Benjelloun W. Phytotherapy of hypertension and diabetes in oriental Morocco. J Ethnopharmacol. 1997;58(1):45-54.

24. Mrabti HN, Jaradat N, Kachmar MR, Ed-Dra A, Ouahbi A, Cherrah Y, et al. Integrative herbal treatments of diabetes in Beni Mellal region of Morocco. J Integr Med. 2019;17(2):93-9.

25. Skalli S, Hassikou R, Arahou M. An ethnobotanical survey of medicinal plants used for diabetes treatment in Rabat, Morocco. Heliyon. 2019;5(3):e01421.

26. Katiri A, Barkaoui M, Msanda F, Boubaker $H$. Ethnobotanical survey of medicinal plants used for the treatment of diabetes in the Tizi nTest region (Taroudant Province, Morocco). J Pharmacogn Nat Prod. 2017;3(1):2472-0992.

27. Hamza N, Berke B, Umar A, Cheze C, Gin H, Moore N. A review of Algerian medicinal plants used in the treatment of diabetes. J Ethnopharmacol. 2019; 238:111841.

28. Oridupa O, Saba A. Diabetes mellitus in Nigeria and the on-going search for a cure from medicinal plants: a review. Afr J Diabetes Med. 2017;25(2):1-3.

29. Shen $Q$, Zhang L, Liao Z, Wang S, Yan T, Shi P, et al. The genome of Artemisia annua provides insight into the evolution of Compositae family and artemisinin biosynthesis. Mol Plant. 2018;11(6):776-88.

30. Uttra AM, Ahsan H, Hasan UH, Chaudhary MA. Traditional medicines of plant origin used for the treatment of inflammatory disorders in Pakistan: a review. J Tradit Chin Med. 2018;38(4):636-56.

31. Bessada SM, Barreira JC, Oliveira MBP. Compositae species with most prominent bioactivity and their potential applications: a review. Ind Crop Prod. 2015;76:604-15.

32. Al-Yahya M, Al-Farhan A, Adam S. Preliminary toxicity study on the individual and combined effects of Citrullus colocynthis and Nerium oleander in rats. Fitoterapia. 2000;71(4):385-91.

33. Boumba VA, Mitselou A, Vougiouklakis T. Fatal poisoning from ingestion of Datura stramonium seeds. Vet Hum Toxicol. 2004;46(2):81-2.

34. Daoubi M, Marquez N, Mazoir N, Benharref A, Hernández-Galán R, Munoz E, et al. Isolation of new phenylacetylingol derivatives that reactivate HIV-1 latency and a novel spirotriterpenoid from Euphorbia officinarum latex. Bioorg Med Chem. 2007;15(13):4577-84.

35. El Malti J, Bourhim N, Amarouch $\mathrm{H}$. Toxicity and antibacterial effect of Mace of Myristica fragrans used in Moroccan gastronomy: biochemical and histological impact. J Food Saf. 2008;28(3):422-41.

36. Almasad MM, Qazan WS, Daradka H. Reproductive toxic effects of Artemisia herba alba ingestion in female Spague-Dawley rats. Pak J Biol Sci. 2007; 10(18):3158-61.

37. Mohammadi RS, Bidaki R, Mirdrikvand F, Yazdi SNM, Anari PY. Peganum Harmala (Aspand) intoxication; a case report. Emerg. 2016;4(2):106.

38. Worbs S, Köhler K, Pauly D, Avondet M-A, Schaer M, Dorner MB, et al. Ricinus communis intoxications in human and veterinary medicine-a summary of real cases. Toxins. 2011;3(10):1332-72.

39. El AHEY, Bousta D, Ouahidi I, Aarab L. Primary pharmacological screening of an endemic plant from the Southern Morocco (Tetraena gaetula [Emb. \& Maire] Beier \& Thulin). C R Biol. 2010;333(10):736-43 [French with abstract in English].

40. Zaoui A, Cherrah Y, Mahassini N, Alaoui K, Amarouch H, Hassar M. Acute and chronic toxicity of Nigella sativa fixed oil. Phytomedicine. 2002;9(1):69-74.

41. Farid O, Hajii L, Eddouks M. Aqueous extract of anabasis aretioides ameliorates Streptozotocininduced diabetes mellitus in rats. Nat Prod J. 2018;8(2):139-46.

42. Chikhi I, Allali H, Dib MEA, Medjdoub H, Tabti B. Antidiabetic activity of aqueous leaf extract of Atriplex halimus L.(Chenopodiaceae) in streptozotocin-induced diabetic rats. Asian Pac J Trop Dis. 2014;4(3):181-4. 
43. Song M-J, Lee S-M, Kim D-K. Antidiabetic effect of Chenopodium ambrosioides. Phytopharm. 2011;1:12-5.

44. Selim YA, Sakeran MI. Effect of time distillation on chemical constituents and anti-diabetic activity of the essential oil from dark green parts of Egyptian Allium ampeloprasum L. J Essent Oil Bear PI. 2014;17(5):838-46.

45. Ozougwu JC. Anti-diabetic effects of Allium cepa (onions) aqueous extracts on alloxan-induced diabetic Rattus novergicus. J Med Plant Res. 2011;5(7): 1134-9.

46. Thomson M, Al-Amin ZM, Al-Qattan KK, Shaban LH. Anti-diabetic and hypolipidaemic properties of garlic (Allium sativum) in streptozotocininduced diabetic rats. Int J Diabetes Metab. 2007;15:108-15.

47. Hashemnia M, Nikousefat Z, Yazdani-Rostam M. Antidiabetic effect of Pistacia atlantica and Amygdalus scoparia in streptozotocin-induced diabetic mice. Comp Clin Pathol. 2015;24(6):1301-6.

48. Rehman MSU, Kamran SH, Ahmad M, Akhtar U. Anti-diabetic activity of crude Pistacia lentiscus in alloxan-induced diabetes in rats. Bangl J Pharmacol. 2015:10(3):543-7.

49. Jouad H, Maghrani M, Eddouks M. Hypoglycemic effect of aqueous extract of Ammi visnaga in normal and streptozotocin-induced diabetic rats. J Herb Pharmacother. 2002;2(4):19-29.

50. El-Ouady F, Eddouks M. Glucose lowering activity of aqueous Ammodaucus leucotrichus extract in diabetic rats. Cardiovasc Hematol Disord Drug Targets. 2019;19:1-8.

51. Gutierrez RMP, Juarez VA, Sauceda JV, Sosa IA. In vitro and in vivo antidiabetic and antiglycation properties of apium graveolens in type 1 and 2 diabetic rats. Int J Pharmacol. 2014;10(7):368-79.

52. Eidi A, Eidi M, Haeri Rohani A, Basati F. Hypoglycemic effect of ethanolic extract of Carum carvi L. seeds in normal and streptozotocin-induced

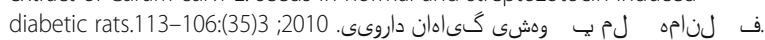

53. Naquvi KJ, Ali M, Ahmad J. Antidiabetic activity of aqueous extract of Coriandrum sativum L. fruits in streptozotocin induced rats. Indian J Exp Biol. 2004;42(9):909-12

54. Srivsatava R, Srivastava SP, Jaiswal N, Mishra A, Maurya R, Srivastava AK. Antidiabetic and antidyslipidemic activities of Cuminum cyminum L. in validated animal models. Med Chem Res. 2011;20(9):1656-66.

55. Pouraboli I, Ranjbar B. Effect of Daucus carota seeds extract on serum levels of glucose, lipids and lipoproteins in type I diabetic male rats. Iranian J Biol. 2011;24(5):679-87.

56. El-Soud N, El-Laithy N, El-Saeed G, Wahby M, Khalil M, Morsy F, et al. Antidiabetic activities of Foeniculum vulgare mill. Essential oil in streptozotocin-induced diabetic rats. Maced J Med Sci. 2011;4(2):139-46.

57. Shobha R, Rajeshwari C, Andallu B. Anti-peroxidative and anti-diabetic activities of aniseeds (Pimpinella anisum L.) and identification of bioactive compounds. Am J Phytomed Clin Ther. 2013;1(5):516-27.

58. Rathod NR, Chitme HR, Irchhaiya R, Chandra R. Hypoglycemic effect of Calotropis gigantea Linn. Leaves and flowers in streptozotocin-induced diabetic rats. Oman Med J. 2011;26(2):104-8.

59. Dra LA, Sellami S, Rais H, Aziz F, Aghraz A, Bekkouche K et al. Antidiabetic potential of Caralluma europaea against alloxan-induced diabetes in mice. Saudi J Biol Sci. 2018;26(6):1-28.

60. Dey P, Saha MR, Chowdhuri SR, Sen A, Sarkar MP, Haldar B, et al. Assessment of anti-diabetic activity of an ethnopharmacological plant Nerium oleander through alloxan induced diabetes in mice. $J$ Ethnopharmacol. 2015;161:128-37.

61. Gaamoussi F, Israili ZH, Lyoussi B. Hypoglycemic and hypolipidemic effects of an aqueous extract of Chamaerops humilis leaves in obese, hyperglycemic and hyperlipidemic Meriones shawi rats. Pak J Pharm Sci. 2010;23(2):121-9.

62. Tohamy AA, Abdalla MS, Ibrahim AK, Mahran KF, Mohammed RS. The effect of Lupinus Albus (Termis) and Hyphaene Thebaica (Doum) on some biochemical parameters in Streptozotocin induced diabetic rats. Egypt J Hosp Med. 2013;31(914):1-6.

63. Algandaby MM, Alghamdi HA, Ashour OM, Abdel-Naim AB, Ghareib SA, Abdel-Sattar EA, et al. Mechanisms of the antihyperglycemic activity of Retama raetam in streptozotocin-induced diabetic rats. Food Chem Toxicol. 2010;48(8-9):2448-53.

64. Rahmy TR, El-Ridi MR. Action of Anastatica hierochuntica plant extract on islets of Langerhans in normal and diabetic rats. Egypt J Biol. 2002;4(1):87-94.

65. Akbari F, Khodadadi S, Asgari S, Shirzad H, Mirhoseini M, Shahinfard N, et al. A comparative study on hypoglycemic properties, lipid profile and bioactive components of hydro-alcoholic extracts of cooked and raw Brassica napus. J Nephropharmacol. 2016;5(2):86.
66. Anand P, Murali K, Tandon V, Chandra R, Murthy P. Preliminary studies on antihyperglycemic effect of aqueous extract of Brassica nigra (L.) Koch in streptozotocin induced diabetic rats. Indian J Exp Biol. 2007;45(8):696-701.

67. Asadujjaman M, Hossain M, Khan M, Anisuzzaman A, Ahmed M, Islam A. Antihyperglycemic and glycogenesis effects of different fractions of brassica oleracea in Alloxan induced diabetic rats. Int J Pharm Sci Res. 2011;2(6):1436.

68. Fard MH, Naseh G, Lotfi N, Hosseini SM, Hosseini M. Effects of aqueous extract of turnip leaf (Brassica rapa) in alloxan-induced diabetic rats. Avicenna J Phytomed. 2015;5(2):148.

69. Chauhan K, Sharma S, Agarwal N, Chauhan S, Chauhan B. A study on potential hypoglycemic and hypolipidemic effects of Lepidium Sativum (garden cress) in Alloxan induced diabetic rats. Am J PharmTech Res. 2012; 2:522-35.

70. Mousa-Al-Reza Hadjzadeh ZR, Moradi R, Ghorbani A. Effects of hydroalcoholic extract of watercress (Nasturtium officinale) leaves on serum glucose and lipid levels in diabetic rats. Indian J Physiol Pharmacol. 2015;59: 223-30.

71. Shukla S, Chatterji S, Mehta S, Rai PK, Singh RK, Yadav DK, et al. Antidiabetic effect of Raphanus sativus root juice. Pharm Biol. 2011:49(1):32-7.

72. Ajebli M, Eddouks M. Buxus sempervirens L improves Streptozotocininduced diabetes mellitus in rats. Cardiovasc Hematol Disord Drug. 2017; 17(2):142-52.

73. Hwang SH, Kang IJ, Lim SS. Antidiabetic effect of fresh nopal (Opuntia ficusindica) in low-dose streptozotocin-induced diabetic rats fed a high-fat diet. Evid Based Complement Alternat Med. 2017;2017:4380721.

74. Rathee S, Mogla O, Sardana S, Vats M, Rathee P. Antidiabetic activity of Capparis decidua Forsk Edgew. J Pharm Res. 2010;3:231-4.

75. Kazemian M, Abad M, Reza Haeri M, Ebrahimi M, Heidari R. Anti-diabetic effect of Capparis spinosa L. root extract in diabetic rats. Avicenna J Phytomed. 2015;5(4):325.

76. Orhan N, Aslan M, Şüküroğlu M, Orhan DD. In vivo and in vitro antidiabetic effect of Cistus laurifolius $L$. and detection of major phenolic compounds by UPLC-TOF-MS analysis. J Ethnopharmacol. 2013;146(3):859-65.

77. Satyanand Tyagi M, Mansoori H, Singh NK, Shivhare MK, Bhardwaj P, Singh RK. Antidiabetic effect of Anacyclus pyrethrum DC in alloxan induced diabetic rats. Eur J Biol Sci. 2011;3(4):117-20.

78. Daradka HM, Abas MM, Mohammad MA, Jaffar MM. Antidiabetic effect of Artemisia absinthium extracts on alloxan-induced diabetic rats. Comp Clin Pathol. 2014;23(6):1733-42.

79. Taştekin D, Atasever M, Adigüzel G, Keleş M, Taştekin A. Hypoglycaemic effect of Artemisia herba-alba in experimental hyperglycaemic rats. Bull Vet Inst Pulawy. 2006;50:235-8.

80. Eddouks M, Lemhadri A, Zeggwagh N, Michel J. Potent hypoglycaemic activity of the aqueous extract of Chamaemelum nobile in normal and streptozotocininduced diabetic rats. Diabetes Res Clin Pract. 2005;67(3):189-95.

81. Pushparaj P, Low H, Manikandan J, Tan B, Tan C. Anti-diabetic effects of Cichorium intybus in streptozotocin-induced diabetic rats. J Ethnopharmacol. 2007;111(2):430-4.

82. Gopal SS, Lakshmi MJ, Sharavana G, Sathaiah G, Sreerama YN, Baskaran V. Lactucaxanthin-a potential anti-diabetic carotenoid from lettuce (Lactuca sativa) inhibits a-amylase and a-glucosidase activity in vitro and in diabetic rats. Food Funct. 2017;8(3):1124-31.

83. Najla O, Olfat A, Kholoud S, Enas N, Hanan S. Hypoglycemic and biochemical effects of Matricaria chamomilla leave extract in streptozotocininduced diabetic rats. J Health Sci. 2012;2(5):43-8.

84. Mir MA, Sawhney S, Jassal M. In-vitro antidiabetic studies of various extracts of Taraxacum officinale. Pharm Innov. 2015;4(1, Part B):61.

85. Hebi M, Eddouks M. Glucose lowering activity of the aqueous extract of Warionia saharae in Normal and diabetic rats. Cardiovasc Hematol Agents Med Chem. 2018;16(1):66-72.

86. Agarwal V, Sharma AK, Upadhyay A, Singh G, Gupta R. Hypoglycemic effects of Citrullus colocynthis roots. Acta Pol Pharm. 2012:69(1):75-9.

87. Karthiyayini T, Kumar R, Kumar KS, Sahu RK, Roy A. Evaluation of antidiabetic and hypolipidemic effect of Cucumis sativus fruit in streptozotocin-induceddiabetic rats. Biomed Pharmacol J. 2015;2(2):351-5.

88. Sharma A, Sharma AK, Chand T, Khardiya M, Yadav KC. Antidiabetic and antihyperlipidemic activity of Cucurbita maxima Duchense (pumpkin) seeds on streptozotocin induced diabetic rats. J Pharmacogn Phytochem. 2013; 1(6):108-16

89. Asgary S, Moshtaghian SJ, Setorki M, Kazemi S, Rafieian-Kopaei M, Adelnia A, et al. Hypoglycaemic and hypolipidemic effects of pumpkin (Cucurbita 
pepo L.) on alloxan-induced diabetic rats. Afr J Pharm Pharmacol. 2011; 5(23):2620-6.

90. Keskes H, Mnafgui K, Hamden K, Damak M, El Feki A, Allouche N. In vitro anti-diabetic, anti-obesity and antioxidant proprieties of Juniperus phoenicea L. leaves from Tunisia. Asian Pac J Trop Biomed. 2014;4:S649-S55.

91. Raut NA, Gaikwad NJ. Antidiabetic activity of hydro-ethanolic extract of Cyperus rotundus in alloxan induced diabetes in rats. Fitoterapia. 2006;77(78):585-8.

92. Bnouham M, Merhfour F, Legssyer A, Mekhfi H, Maâllem S, Ziyyat A. Antihyperglycemic activity of Arbutus unedo, Ammoides pusilla and Thymelaea hirsuta. Pharmazie. 2007;62(8):630-2.

93. Shokeen P, Anand P, Murali YK, Tandon V. Antidiabetic activity of 50\% ethanolic extract of Ricinus communis and its purified fractions. Food Chem Toxicol. 2008;46(11):3458-66.

94. Liyanage R, Kiramage C, Visvanathan R, Jayathilake C, Weththasinghe P, Bangamuwage $R$, et al. Hypolipidemic and hypoglycemic potential of raw, boiled, and sprouted mung beans (Vigna radiata L. Wilczek) in rats. J Food Biochem. 2018;42(1):e12457.

95. Ashraduzzaman M, Alam M, Khatun S, Banu S, Absar N. Vigna unguiculata Linn. Walp. Seed oil exhibiting antidiabetic effects in alloxan induced diabetic rats. Malays J Pharm Sci. 2011;9(1):13-23.

96. Mansar-Benhamza L, Djerrou Z, Pacha H. Evaluation of anti-hyperglycemic activity and side effects of Erythraea centaurium (L.) Pers. in rats. Afr J Biotechnol. 2013;12(50):6980-5.

97. Mohajeri D, Mousavi G, Doustar Y. Antihyperglycemic and pancreasprotective effects of Crocus sativus L.(saffron) stigma ethanolic extract on rats with alloxan-induced diabetes. J Biol Sci. 2009;9(4):302-10.

98. Mohammadi J, Saadipour K, Delaviz H, Mohammadi B. Anti-diabetic effects of an alcoholic extract of Juglans regia in an animal model. Turk J Med Sci. 2011;41(4):685-91.

99. El Hilaly J, Lyoussi B. Hypoglycaemic effect of the lyophilised aqueous extract of Ajuga Iva in normal and streptozotocin diabetic rats. J Ethnopharmacol. 2002;80(2-3):109-13.

100. Issa A, Mohammad M, Hudaib M, Tawah K, Rjai TA, Oran S, et al. A potential role of Lavandula angustifolia in the management of diabetic dyslipidemia. J Med Plant Res. 2011;5(16):3876-82.

101. Sebai H, Selmi S, Rtibi K, Souli A, Gharbi N, Sakly M. Lavender (Lavandula stoechas L.) essential oils attenuate hyperglycemia and protect against oxidative stress in alloxan-induced diabetic rats. Lipids Health Dis. 2013; 12(1):189.

102. Elberry AA, Harraz FM, Ghareib SA, Gabr SA, Nagy AA, Abdel-Sattar E. Methanolic extract of Marrubium vulgare ameliorates hyperglycemia and dyslipidemia in streptozotocin-induced diabetic rats. Int J Diabetes Mellitus. 2015;3(1):37-44.

103. El-Beshbishy H, Bahashwan S. Hypoglycemic effect of basil (Ocimum basilicum) aqueous extract is mediated through inhibition of a-glucosidase and aamylase activities: an in vitro study. Toxicol Ind Health. 2012;28(1):42-50.

104. Bakırel T, Bakırel U, Keleş OÜ, Ülgen SG, Yardibi H. In vivo assessment of antidiabetic and antioxidant activities of rosemary (Rosmarinus officinalis) in alloxan-diabetic rabbits. J Ethnopharmacol. 2008;116(1):64-73.

105. Eidi A, Eidi M. Antidiabetic effects of sage (Salvia officinalis L.) leaves in normal and streptozotocin-induced diabetic rats. Diabetes Metab Syndr. 2009;3(1):40-4.

106. Gharaibeh MN, Elayan HH, Salhab AS. Hypoglycemic effects of Teucrium polium. J Ethnopharmacol. 1988;24(1):93-9.

107. Kabbaoui M, Chda A, Mejrhit N, Azdad O, Farah A, Aarab L, et al. Antidiabetic effect of Thymus satureioides aqueous extract in streptozotocin-induced diabetic rats. Int J Pharm Pharm Sci. 2016;8(9):140-5.

108. Aljarah AK, Hameed IH. In vitro anti-diabetic properties of Methanolic extract of Thymus vulgaris using a-glucosidase and a-amylase inhibition assay and determination of its bioactive chemical compounds. Indian J Public Health Res Dev. 2018;9(3):388-92.

109. Kamble S, Rambhimaiah S. Antidiabetic activity of aqueous extract of Cinnamomum cassia in alloxan-induced diabetic rats. Biomed Pharmacol J. 2015;6(1):83-8

110. El-Desoky GE, Aboul-Soud MA, Al-Numair KS. Antidiabetic and hypolipidemic effects of Ceylon cinnamon (Cinnamomum verum) in alloxan-diabetic rats. J Med Plant Res. 2012;6(9):1685-91.

111. Basak SS, Candan F. Effect of Laurus nobilis L. essential oil and its main components on a-glucosidase and reactive oxygen species scavenging activity. Iran J Pharm Res. 2013;12(2):367.
112. Ezejiofor AN, Okorie A, Orisakwe OE. Hypoglycaemic and tissue-protective effects of the aqueous extract of Persea americana seeds on alloxaninduced albino rats. Malays J Med Sci. 2013;20(5):31.

113. Ahmad M, Zaman F, Sharif T, Ch MZ. Antidiabetic and hypolipidemic effects of aqueous methanolic extract of Acacia nilotica pods in alloxan-induced diabetic rabbits. Scand J Lab Anim Sci. 2008;35(1):29-34.

114. Batra S, Batra N, Nagori BP. Preliminary phytochemical studies and evaluation of antidiabetic activity of stem bark of Acacia Senegal (L.) Willd. In alloxan induced diabetic albino rats. Int J Med Res Rev. 2013;1(8):611-6.

115. Alharbi WDM, Azmat A. Hypoglycemic and hypocholesterolemic effects of Acacia tortilis (Leguminosae) growing in Makkah. Pak J Pharmacol. 2011; 28(1):1-8.

116. Bilbis L, Shehu R, Abubakar M. Hypoglycemic and hypolipidemic effects of aqueous extract of Arachis hypogaea in normal and alloxan-induced diabetic rats. Phytomedicine. 2002;9(6):553-5.

117. Umar I, Mohammad A, Ndidi U, Abdulazeez A, Olica W, Adam M. Antihyperglycemic and antihyperlipidemic effect of aqueous stem bark extract of Acacia albida Delile in alloxan-induced diabetic rats. Asian J Biochem. 2014;9:170-8.

118. Badole SL, Bodhankar SL. Investigation of antihyperglycemic activity of Glycine max (L.) Merr. on serum glucose level in diabetic mice. J Complement Integr Med. 2009;6(1):1-15.

119. Knecht KT, Nguyen $H$, Auker AD, Kinder DH. Effects of extracts of lupine seed on blood glucose levels in glucose resistant mice: antihyperglycemic effects of Lupinus albus (white lupine, Egypt) and Lupinus caudatus (tailcup lupine, Mesa Verde National Park). J Herb Pharmacother. 2006;6(3-4):89-104.

120. Helal EG, Abd El-Wahab SM, Atia TA. Hypoglycemic effect of the aqueous extracts of Lupinus albus, Medicago sativa (seeds) and their mixture on diabetic rats. Egypt J Hosp Med. 2013;31(708):1-15.

121. Atchibri A, Brou K, Kouakou T, Kouadio Y, Gnakri D. Screening for antidiabetic activity and phytochemical constituents of common bean (Phaseolus vulgaris L.) seeds. J Med Plant Res. 2010;4(17):1757-61.

122. Vats V, Grover J, Rathi S. Evaluation of anti-hyperglycemic and hypoglycemic effect of Trigonella foenum-graecum Linn, Ocimum sanctum Linn and Pterocarpus marsupium Linn in normal and alloxanized diabetic rats. J Ethnopharmacol. 2002;79(1):95-100.

123. Ghule AE, Jadhav SS, Bodhankar SL. Effect of ethanolic extract of seeds of Linum usitatissimum (Linn.) in hyperglycaemia associated ROS production in PBMNCs and pancreatic tissue of alloxan induced diabetic rats. Asian Pac J Trop Dis. 2012;2(5):405-10.

124. Choubey A, Ojha M, Mishra A, Mishra S, Patil U. Hypoglycemic and antihyperglycemic effect of ethanolic extract of whole plant of Lawsonia inermis (henna) in streptozotocin induced diabetic rats. Int J Pharm Sci Res. 2010;1:74-7.

125. Das S, Barman S. Antidiabetic and antihyperlipidemic effects of ethanolic extract of leaves of Punica granatum in alloxan-induced non-insulindependent diabetes mellitus albino rats. Indian J Pharm. 2012;44(2):219.

126. Sabitha V, Ramachandran S, Naveen K, Panneerselvam K. Antidiabetic and antihyperlipidemic potential of Abelmoschus esculentus (L.) Moench. in streptozotocin-induced diabetic rats. J Pharm Bioallied Sci. 2011;3(3):397.

127. Ademiluyi AO, Oboh G. Aqueous extracts of Roselle (Hibiscus sabdariffa Linn.) varieties inhibit a-amylase and a-glucosidase activities in vitro. J Med Food. 2013;16(1):88-93.

128. Perez C, Dominguez E, Canal J, Campillo J, Torres M. Hypoglycaemic activity of an aqueous extract from Ficus carica (fig tree) leaves in streptozotocin diabetic rats. Pharm Biol. 2000;38(3):181-6.

129. Singab ANB, El-Beshbishy HA, Yonekawa M, Nomura T, Fukai T. Hypoglycemic effect of Egyptian Morus alba root bark extract: effect on diabetes and lipid peroxidation of streptozotocin-induced diabetic rats. J Ethnopharmacol. 2005;100(3):333-8.

130. Lakshmi V, Agarwal S, Ansari JA, Mahdi AA, Srivastava A. Antidiabetic potential of Musa paradisiaca in Streptozotocin-induced diabetic rats. J Phytopharmacol. 2014;3:77-81.

131. Somani R, Singhai A. Hypoglycaemic and antidiabetic activities of seeds of Myristica fragrans in normoglycaemic and alloxan-induced diabetic rats. Asian J Exp Sci. 2008;22(1):95-102.

132. Basak SS, Candan F. Chemical composition and in vitro antioxidant and antidiabetic activities of Eucalyptus camaldulensis Dehnh. Essential oil. J Iran Chem Soc. 2010;7(1):216-26.

133. Jouad H, Maghrani M, Hassani RE, Eddouks M. Hypoglycemic activity of aqueous extract of Eucalyptus globulus in normal and streptozotocininduced diabetic rats. Int J Geogr Inf Syst. 2004;10(4):19-28. 
134. Panjeshahin MR, Azadbakht M, Akbari N. Antidiabetic activity of different extracts of Myrtus communis in streptozotocin induced diabetic rats. Rom J Diabetes Nutr Metab Dis. 2016;23(2):183-90.

135. Tahir HU, Sarfraz RA, Ashraf A, Adil S. Chemical composition and antidiabetic activity of essential oils obtained from two spices (Syzygium aromaticum and Cuminum cyminum). Int J Food Prop. 2016;19(10):2156-64.

136. Medjahed Z, Atman-Kilani D, Fauconnier M-L, Richard G, Atmani D. Hepatoprotective and antidiabetic activities of Fraxinus angustifolia Vahl extracts in animal models: characterization by high performance liquid chromatography analysis. Turk J Med Sci. 2016;46(3):910-20.

137. Eidi A, Eidi M, Darzi R. Antidiabetic effect of Olea europaea L. in normal and diabetic rats. Phytother Res. 2009;23(3):347-50.

138. Bhuvaneswari P, Krishnakumari S. Antihyperglycemic potential of Sesamum indicum (Linn) seeds in streptozotocin induced diabetic rats. Int J Pharm Pharm Sci. 2012:4(1):527-31.

139. Jouad H, Maghrani M, Eddouks M. Hypoglycaemic effect of Rubus fructicosis L. and Globularia alypum L. in normal and streptozotocininduced diabetic rats. J Ethnopharmacol. 2002;81(3):351-6.

140. Singh SK, Kesari AN, Gupta RK, Jaiswal D, Watal G. Assessment of antidiabetic potential of Cynodon dactylon extract in streptozotocin diabetic rats. J Ethnopharmacol. 2007;114(2):174-9.

141. Minaiyan M, Ghannadi A, Movahedian A, Hakim-Elahi I. Effect of Hordeum vulgare L.(Barley) on blood glucose levels of normal and STZ-induced diabetic rats. Res Pharm Sci. 2014;9(3):173.

142. Prasad SV, Natava R, Sirasanagandla S, Rao CA. Anti hyperglycemic and antioxidant effects of Pennisetum glaucum seed extracts in STZ induced diabetic rats. J Pharm Chem. 2012;6(3):36-42.

143. Estrada-Salas PA, Montero-MoráN GM, Martínez-Cuevas PP, GonzáLez C. Barba De La Rosa AP. Characterization of antidiabetic and antihypertensive properties of canary seed (Phalaris canariensis L.) peptides. J Agric Food Chem. 2014;62(2):427-33.

144. Kim J, Park Y. Anti-diabetic effect of sorghum extract on hepatic gluconeogenesis of streptozotocin-induced diabetic rats. Nutr Metab. 2012;9(1):106.

145. Sabiu S, O'neill F, Ashafa A. Kinetics of a-amylase and a-glucosidase inhibitory potential of Zea mays Linnaeus (Poaceae), stigma maydis aqueous extract: an in vitro assessment. J Ethnopharmacol. 2016;183:1-8.

146. Alimohammadi S, Hobbenaghi R, Javanbakht J, Kheradmand D, Mortezaee $\mathrm{R}$, Tavakoli $\mathrm{M}$, et al. Protective and antidiabetic effects of extract from Nigella sativa on blood glucose concentrations against streptozotocin (STZ)induced diabetic in rats: an experimental study with histopathological evaluation. Diagn Pathol. 2013;8(1):137.

147. Marmouzi I, Kharbach M, El Jemli M, Bouyahya A, Cherrah Y, Bouklouze A, et al. Antidiabetic, dermatoprotective, antioxidant and chemical functionalities in Zizyphus lotus leaves and fruits. Ind Crop Prod. 2019;132: 134-9.

148. Mirmohammadlu M, Hosseini SH, Kamalinejad M, Gavgani ME, Noubarani M, Eskandari MR. Hypolipidemic, hepatoprotective and renoprotective effects of Cydonia oblonga Mill. fruit in streptozotocin-induced diabetic rats. Iran J Pharm Res. 2015;14(4):1207.

149. Sancheti S, Sancheti S, Seo S-Y. Antidiabetic and antiacetylcholinesterase effects of ethyl acetate fraction of Chaenomeles sinensis (Thouin) Koehne fruits in streptozotocin-induced diabetic rats. Exp Toxicol Pathol. 2013;65(12):55-60.

150. Wadood N, Wadood A, Hidayat H, Wahid S. Effect on Eriobotrya japonica on blood glucose levels of normal and alloxan diabetic rabbits. Planta Med. 1988;25:1-6.

151. Raafat K, El-Darra N, Saleh FA, Rajha HN, Maroun RG, Louka N. Infrared-assisted extraction and HPLC-analysis of Prunus armeniaca L. pomace and detoxifiedkernel and their antidiabetic effects. Phytochem Anal. 2018;29(2):156-67.

152. Qureshi MN, Numonov S, Abudurexiti A, Aisa HA. Phytochemical investigations and evaluation of antidiabetic potential of Prunus dulcis nuts. LWT Food Sci Technol. 2016;66:311-7.

153. Sah AN, Joshi A, Juyal V, Kumar T. Antidiabetic and hypolipidemic activity of Citrus medica Linn. Seed extract in streptozotocin induced diabetic rats. Pharm J. 2011;3(23):80-4

154. Oboh G, Ademosun A. Phenolic extracts from grapefruit peels (Citrus paradisi) inhibit key enzymes linked with type 2 diabetes and hypertension. J Food Biochem. 2011;35(6):1703-9.

155. Kumar PRZA, Bhaskar A. Evaluation of antihyperglycaemic and antihyperlipidemic activity of Citrus sinensis peel extract on streptozotocininduced diabetic rats. Int J Diabetes Dev C. 2015;35(4):448-53.
156. Sharma M, Fernandes J, Ahirwar D, Jain R. Hypoglycemic and hypolipidimic activity of alcoholic extract of Citrus aurantium in normal and alloxaninduced diabetic rats. Pharmacologyonline. 2008;3:161-71.

157. Ahmed OM, Moneim AA, Yazid IA, Mahmoud AM. Antihyperglycemic, antihyperlipidemic and antioxidant effects and the probable mechanisms of action of Ruta graveolens infusion and rutin in nicotinamide-streptozotocininduced diabetic rats. Diabetol Croat. 2010;39(1):15-35.

158. Farid O, Hebi M, Ajebli M, Hidani AE, Eddouks M. Antidiabetic effect of Ruta montana L. in streptozotocin-induced diabetic rats. J Basic Clin Physiol Pharmacol. 2017;28(3):275-82.

159. Ohiri F, Esimone C, Nwafor S, Okoli C, Ndu O. Hypoglycemic properties of Viscum album (mistletoe) in alloxan-induced diabetic animals. Pharm Biol. 2003:41(3):184-7.

160. Hebi M, Khallouki F, Haidani A, Eddouks M. Aqueous extract of Argania spinosa $L$. fruits ameliorates diabetes in streptozotocin-induced diabetic rats. Cardiovasc Hematol Agents Med Chem. 2018;16(1):56-65.

161. Kwon Yl, Apostolidis E, Shetty K. Evaluation of pepper (Capsicum annuum) for management of diabetes and hypertension. J Food Biochem. 2007;31(3):370-85.

162. Shobha G, Soumya C, Shashidhara K, Moses V. Phytochemical profile, antibacterial and antidiabetic effects of crude aqueous leaf extract of datura stramonium. Pharmacophore. 2014;5(2):273-8.

163. Ademosun A, Oboh G, Adewuni T, Akinyemi A, Olasehinde T. Antioxidative properties and inhibition of key enzymes linked to type-2 diabetes by snake tomato (Tricosanthes cucumerina) and two tomato (Lycopersicon esculentum) varieties. Afr J Pharm Pharmacol. 2013;7(33):2358-65.

164. Kazeem MI, Ogungbe SM, Saibu GM, Aboyade OM. In vitro study on the hypoglycemic potential of Nicotiana tabacum leaf extracts. Bangl J Pharmacol. 2014;9(2):140-5.

165. Poongothai K, Ahmed KSZ, Ponmurugan P, Jayanthi M. Assessment of antidiabetic and antihyperlipidemic potential of Solanum nigrum and Musa paradisiaca in alloxan induced diabetic rats. J Pharm Res. 2010;3(9):2203-5.

166. Gomes A, Vedasiromoni J, Das M, Sharma R, Ganguly D. Anti-hyperglycemic effect of black tea (Camellia sinensis) in rat. J Ethnopharmacol. 1995;45(3): 223-6.

167. El Amrani F, Rhallab A, Alaoui T, El Badaoui K, Chakir S. Hypoglycaemic effect of Thymelaea hirsuta in normal and streptozotocin-induced diabetic rats. J Med Plant Res. 2009;3(9):625-9.

168. Bnouham M, Merhfour F-Z, Ziyyat A, Mekhfi H, Aziz M, Legssyer A. Antihyperglycemic activity of the aqueous extract of Urtica dioica. Fitoterapia. 2003;74(7-8):677-81.

169. Kavalalı G, Tuncel H, Göksel S, Hatemi H. Hypoglycemic activity of Urtica pilulifera in streptozotocin-diabetic rats. J Ethnopharmacol. 2003;84(2-3): 241-5.

170. Şendoğdu N, Aslan M, Orhan DD, Ergun F, Yeşilada E. Antidiabetic and antioxidant effects of Vitis vinifera L. leaves in streptozotocin-diabetic rats. Turkish J Pharm Sci. 2006;3(1):7-18.

171. Al-Amin ZM, Thomson M, Al-Qattan KK, Peltonen-Shalaby R, Ali M. Antidiabetic and hypolipidaemic properties of ginger (Zingiber officinale) in streptozotocin-induced diabetic rats. Br J Nutr. 2006:96(4):660-6.

172. Aher R, Belge S, Kadam S, Kharade S, Misal A, Yeole P. Therapeutic importance of fenugreek (Trigonella foenum-graecum L.): a review. J Plant Sci Res. 2016;3(1):149.

173. Shashikumar J, Champawat P, Mudgal V, Jain S, Deepak S, Mahesh K. A review: food, medicinal and nutraceutical properties of fenugreek (Trigonella Foenum-Graecum L.). Int J Chem Stud. 2018;6(2):1239-45.

174. Wani SA, Kumar P. Fenugreek: a review on its nutraceutical properties and utilization in various food products. J Saudi Soc Agric Sci. 2018;17(2):97-106.

175. Goyal S, Gupta N, Chatterjee S. Investigating therapeutic potential of Trigonella foenum-graecum L. as our defense mechanism against several human diseases. J Toxicol. 2016;2016:1-10.

176. Zameer S, Najmi AK, Vohora D, Akhtar M. A review on therapeutic potentials of Trigonella foenum graecum (fenugreek) and its chemical constituents in neurological disorders: complementary roles to its hypolipidemic, hypoglycemic, and antioxidant potential. Nutr Neurosci. 2018;21(8):539-45.

177. Xue WL, Li XS, Zhang J, Liu YH, Wang ZL, Zhang RJ. Effect of Trigonella foenum-graecum (fenugreek) extract on blood glucose, blood lipid and hemorheological properties in streptozotocin-induced diabetic rats. Asia Pac J Clin Nutr. 2007;16(S1):422-6.

178. Abdelatif AM, Ibrahim MY, Mahmoud AS. Antidiabetic effects of fenugreek (Trigonella foenum-graecum) seeds in the domestic rabbit (Oryctolagus cuniculus). Res J Med Plant. 2012;6(6):449-55. 
179. Khlifi S, Ben Jemaa H, Ben Hmad H, Abaza H, Karmous I, Abid A, et al. Antioxidant, antidiabetic and antihyperlipidemic effects of Trigonella foenum-graecum seeds. Int J Pharmacol. 2016;12:394-400.

180. Puri D, Prabhu K, Murthy P. Mechanism of action of a hypoglycemic principle isolated from fenugreek seeds. Indian J Physiol Pharmacol. 2002; 46(4):457-62.

181. Bertella A, Benlahcen K, Abouamama S, Pinto DC, Maamar K, Kihal M, et al. Artemisia herba-alba Asso. Essential oil antibacterial activity and acute toxicity. Ind Crop Prod. 2018;116:137-43.

182. Nedjimi B, Zemmiri H. Salinity effects on germination of Artemisia herbaalba Asso: important pastoral shrub from north African rangelands. Rangel Ecol Manag. 2019;72(1):189-94.

183. Hamad HM. Evaluation of Allelopathic Potential of Artemisia herba-alba on Germination and Seedling Growth of Raphanus sativus and Trigonella foenum-graecum. Asian J Biol. 2019;8(1):1-7.

184. Laadraoui J, Aboufatima R, El Gabbas Z, Ferehan H, Bezza K, Laaradia MA, et al. Effect of Artemisia herba-alba consumption during pregnancy on fertility, morphological and behaviors of mice offspring. J Ethnopharmacol. 2018:226:105-10.

185. Yashphe J, Segal R, Breuer A, Erdreich-Naftali G. Antibacterial activity of Artemisia herba-alba. J Pharm Sci. 1979;68(7):924-5.

186. Hatimi S, Boudouma M, Bichichi M, Chaib N, Idrissi NG. Evaluation in vitro de l'activité antileishmanienne d'Artemisia herba-alba Asso. Bull Soc Pathol Exot. 2001;94:29-31.

187. Mighri $H$, Hajlaoui $H$, Akrout A, Najjaa H, Neffati M. Antimicrobial and antioxidant activities of Artemisia herba-alba essential oil cultivated in Tunisian arid zone. C R Chim. 2010;13(3):380-6.

188. Yashphe J, Feuerstein I, Barel S, Segal R. The antibacterial and antispasmodic activity of Artemisia herba alba Asso. II. Examination of essential oils from various chemotypes. Int J Crude Drug Res. 1987;25(2):89-96.

189. Dob T, Benabdelkader T. Chemical composition of the essential oil of Artemisia herba-alba Asso grown in Algeria. J Essent Oil Res. 2006;18(6):685-90.

190. Hudaib MM, Aburjai TA. Composition of the essential oil from Artemisia herba-alba grown in Jordan. J Essent Oil Res. 2006;18(3):301-4.

191. Feuerstein I, Danin A, Segal R. Constitution of the essential oil from an Artemisia herba-alba population of Spain. Phytochemistry. 1988;27(2):433-4.

192. Salido S, Valenzuela LR, Altarejos J, Nogueras M, Sánchez A, Cano E. Composition and infraspecific variability of Artemisia herba-alba from southern Spain. Biochem Syst Ecol. 2004;32(3):265-77.

193. Awad NE, Seida AA, Shaffie Z, El-Aziz AMA, Awad N. Hypoglycemic activity of Artemisia herba-alba (Asso.) used in Egyptian traditional medicine as hypoglycemic remedy. J Appl Pharm Sci. 2012;2(03):30-9.

194. Hamza N, Berke B, Cheze C, Le Garrec R, Lassalle R, Agli A-N, et al. Treatment of high fat diet induced type 2 diabetes in C57BL/6J mice by two medicinal plants used in traditional treatment of diabetes in the east of Algeria. J Ethnopharmacol. 2011;133(2):931-3.

195. Sharma N, Ahirwar D, Jhade D, Gupta S. Medicinal and phamacological potential of nigella sativa: a review. Ethnobot Leafl. 2009;2009(7):11.

196. Tembhurne S, Feroz S, More B, Sakarkar D. A review on therapeutic potential of Nigella sativa (kalonji) seeds. J Med Plant Res. 2014;8(3):167-77.

197. Mollazadeh $\mathrm{H}$, Hosseinzadeh $\mathrm{H}$. The protective effect of Nigella sativa against liver injury: a review. Iran J Basic Med Sci. 2014;17(12):958.

198. Ali B, Blunden G. Pharmacological and toxicological properties of Nigella sativa. Phytother Res. 2003;17(4):299-305.

199. Ahmad A, Husain A, Mujeeb M, Khan SA, Najmi AK, Siddique NA, et al. A review on therapeutic potential of Nigella sativa: a miracle herb. Asian Pac J Trop Biomed. 2013;3(5):337-52.

200. Kooti W, Hasanzadeh-Noohi Z, Sharafi-Ahvazi N, Asadi-Samani M, AshtaryLarky D. Phytochemistry, pharmacology, and therapeutic uses of black seed (Nigella sativa). Chin J Nat Med. 2016;14(10):732-45.

201. Houcher Z, Boudiaf K, Benboubetra M, Houcher B. Effects of methanolic extract and commercial oil of Nigella sativa L. on blood glucose and antioxidant capacity in alloxan-induced diabetic rats. Pteridines. 2007;18(1):8-18.

202. Al-Hader A, Aqel M, Hasan Z. Hypoglycemic effects of the volatile oil of Nigella sativa seeds. Int J Pharmacogn. 1993;31(2):96-100

203. Guo Z, Jia X, Zheng Z, Lu X, Zheng Y, Zheng B, et al. Chemical composition and nutritional function of olive (Olea europaea L.): a review. Phytochem Rev. 2018;17(5):1091-110.

204. Hashmi MA, Khan A, Hanif M, Farooq U, Perveen S. Traditional uses, phytochemistry, and pharmacology of Olea europaea (olive). Evid Based Complement Alternat Med. 2015;2015:1-29.
205. Özcan MM, Matthäus B. A review: benefit and bioactive properties of olive (Olea europaea L.) leaves. Eur Food Res Technol. 2017;243(1):89-99.

206. Şahin S, Bilgin M. Olive tree (Olea europaea L.) leaf as a waste by-product of table olive and olive oil industry: a review. J Sci Food Agric. 2018;98(4): 1271-9.

207. Sato H, Genet C, Strehle A, Thomas C, Lobstein A, Wagner A, et al. Antihyperglycemic activity of a TGR5 agonist isolated from Olea europaea. Biochem Biophys Res Commun. 2007;362(4):793-8.

208. El-Amin M, Virk P, Elobeid M, Almarhoon ZM, Hassan ZK, Omer SA, et al. Anti-diabetic effect of Murraya koenigii $(L)$ and Olea europaea $(L)$ leaf extracts on streptozotocin induced diabetic rats. Pak J Pharm Sci. 2013;26(2): 359-65.

209. Wainstein J, Ganz T, Boaz M, Bar Dayan Y, Dolev E, Kerem Z, et al. Olive leaf extract as a hypoglycemic agent in both human diabetic subjects and in rats. J Med Food. 2012:15(7):605-10.

210. Kaeidi A, Esmaeili-Mahani S, Sheibani V, Abbasnejad M, Rasoulian B, Hajializadeh Z, et al. Olive (Olea europaea L.) leaf extract attenuates early diabetic neuropathic pain through prevention of high glucose-induced apoptosis: in vitro and in vivo studies. J Ethnopharmacol. 2011;136(1):188-96.

211. Al-Attar AM, Alsalmi FA. Effect of Olea europaea leaves extract on streptozotocin induced diabetes in male albino rats. Saudi J Biol Sci. 2017; 26(1):118-28.

212. Choudhury M, Mostofa M, Awal M. Antidiabetic effects of Azadirachta indica, Trigonella foenumgraecum, Olea europea and Glibenclamide in experimentally diabetic induced rat. J Bangladesh Agric Univ. 2005;3(4522018-3844):277-82.

213. Sangi SMA, Sulaiman MI, El-Wahab MFA, Ahmedani El, Ali SS. Antihyperglycemic effect of thymoquinone and oleuropein, on streptozotocin-induced diabetes mellitus in experimental animals. Pharmacogn Mag. 2015;11(Suppl 2):S251.

214. Afify A, El-Beltagi HS, Fayed SA, El-Ansary AE. Hypoglycemic and iron status ameliorative effects of Olea europea CV.'Picual'leaves extract in streptozotocin induced diabetic rats. Fresenius Environ Bull. 2017;26:6898-908.

215. Al-Azzawie HF, Alhamdani MS. Hypoglycemic and antioxidant effect of oleuropein in alloxan-diabetic rabbits. Life Sci. 2006;78(12):1371-7.

216. Jemai $H$, El Feki A, Sayadi S. Antidiabetic and antioxidant effects of hydroxytyrosol and oleuropein from olive leaves in alloxan-diabetic rats. J Agric Food Chem. 2009;57(19):8798-804.

217. Qadir NM, Ali KA, Qader SW. Antidiabetic effect of oleuropein from olea europaea leaf against alloxan induced type 1 diabetic in rats. Braz Arch Biol Technol. 2016:59:1-10.

218. Benhabyles N, Arab K, Bouchenak O, Baz A. Phytochemical screening, hypoglycemic and antihyperglycemic effect of flavonoids from the leaves of Algerian Olea europaea L. in normal and alloxan-induced diabetic rats. Int J Pharm. 2015;11:477-83.

219. Gonzalez M, Zarzuelo A, Gamez M, Utrilla M, Jimenez J, Osuna I. Hypoglycemic activity of olive leaf. Planta Med. 1992;58(06):513-5.

220. Hadrich F, Bouallagui Z, Junkyu H, Isoda H, Sayadi S. The a-glucosidase and a-amylase enzyme inhibitory of hydroxytyrosol and oleuropein. J Oleo Sci. 2015;64(8):835-43

221. Khlif I, Hamden K, Damak M, Allouche N. A new triterpene from Olea europea stem with antidiabetic activity. Chem Nat Compd. 2012;48(5):799-802.

222. Marrelli M, Amodeo V, Statti G, Conforti F. Biological properties and bioactive components of Allium cepa L.: Focus on potential benefits in the treatment of obesity and related comorbidities. Molecules. 2019;24(1):119.

223. Etana MB, Aga MC, Fufa BO. Major onion (Allium cepa L.) production challenges in Ethiopia: a review. J Biol Agric Healthc. 2019;9(7):42-7.

224. Teshika JD, Zakariyyah AM, Zaynab T, Zengin G, Rengasamy KR, Pandian SK, et al. Traditional and modern uses of onion bulb (Allium cepa L.): a systematic review. Crit Rev Food Sci Nutr. 2019;59(sup1):S39-70.

225. Kumar KS, Bhowmik D, Chiranjib B, Tiwari P. Allium cepa: a traditional medicinal herb and its health benefits. J Chem Pharm Res. 2010;2(1):283-91.

226. Prakash D, Singh BN, Upadhyay G. Antioxidant and free radical scavenging activities of phenols from onion (Allium cepa). Food Chem. 2007;102(4): 1389-93.

227. Vian MA, Fabiano-Tixier A-S, Elmaataoui M, Dangles O, Chemat F. A remarkable influence of microwave extraction: enhancement of antioxidant activity of extracted onion varieties. Food Chem. 2011;127(4):1472-80.

228. Zhang SL, Peng D, Xu YC, Lü SW, Wang JJ. Quantification and analysis of anthocyanin and flavonoids compositions, and antioxidant activities in onions with three different colors. J Integr Agric. 2016;15(9):2175-81. 
229. Pérez-Gregorio RM, García-Falcón MS, Simal-Gándara J, Rodrigues AS, Almeida DP. Identification and quantification of flavonoids in traditional cultivars of red and white onions at harvest. J Food Compos Anal. 2010; 23(6):592-8.

230. Griffiths G, Trueman L, Crowther T, Thomas B, Smith B. Onions-a global benefit to health. Phytother Res. 2002;16(7):603-15.

231. El-Demerdash F, Yousef M, El-Naga NA. Biochemical study on the hypoglycemic effects of onion and garlic in alloxan-induced diabetic rats. Food Chem Toxicol. 2005:43(1):57-63.

232. Kumari K, Augusti K. Antidiabetic and antioxidant effects of S-methyl cysteine sulfoxide isolated from onions (Allium cepa Linn) as compared to standard drugs in alloxan diabetic rats. Indian J Exp Biol. 2002;40(9):1005-9.

233. El-Soud N, Khalil M. Antioxidative effects of Allium cepa essential oil in streptozotocin induced diabetic rats. Maced J Med Sci. 2010;3(4):344-51.

234. Bahammou Y, Tagnamas Z, Lamharrar A, Idlimam A. Thin-layer solar drying characteristics of Moroccan horehound leaves (Marrubium vulgare L.) under natural and forced convection solar drying. Sol Energy. 2019;188:958-69.

235. Zawiślak G. The chemical composition of the essential oil of Marrubium vulgare L. from Poland. Farm. 2012;60(2):287-92.

236. Bokaeian M, Saboori E, Saeidi S, Niazi AA, Amini-Borojeni N, Khaje H, et al. Phytochem anal, antibacterial activity of Marrubium vulgare $L$ against Staphylococcus aureus in vitro. Zahedan J Res Med Sci. 2014;16(10):60-4.

237. Paula De Oliveira A, Santin JR, Lemos M, Klein Júnior LC, Couto AG, Meyre Da Silva Bittencourt C, et al. Gastroprotective activity of methanol extract and marrubiin obtained from leaves of Marrubium vulgare L.(Lamiaceae). J Pharm Pharmacol. 2011:63(9):1230-7.

238. Amri B, Martino E, Vitulo F, Corana F, Kaâb LB-B, Rui M, et al. Marrubium vulgare L. Leave extract: Phytochemical composition, antioxidant and wound healing properties. Molecules. 2017;22(11):1851.

239. Boudjelal A, Henchiri C, Siracusa L, Sari M, Ruberto G. Compositional analysis and in vivo anti-diabetic activity of wild Algerian Marrubium vulgare L. infusion. Fitoterapia. 2012;83(2):286-92.

240. Vergara-Galicia J, Aguirre-Crespo F, Tun-Suarez A, Aguirre-Crespo A, EstradaCarrillo M, Jaimes-Huerta I, et al. Acute hypoglycemic effect of ethanolic extracts from Marrubium vulgare. Phytopharm. 2012;3(1):54-60.

\section{Publisher's Note}

Springer Nature remains neutral with regard to jurisdictional claims in published maps and institutional affiliations.

\section{Submit your manuscript to a SpringerOpen ${ }^{\circ}$ journal and benefit from:}

- Convenient online submission

- Rigorous peer review

- Open access: articles freely available online

- High visibility within the field

- Retaining the copyright to your article

Submit your next manuscript at $\boldsymbol{\nabla}$ springeropen.com 